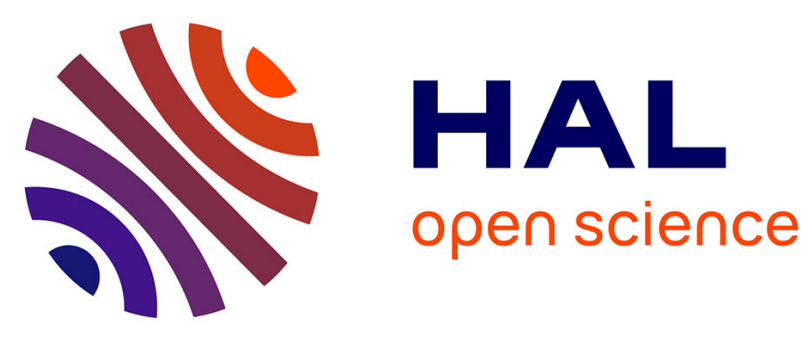

\title{
Synthesis of Protected 3,4- and \\ 2,3-Dimercaptophenylalanines as Building Blocks for Fmoc -Peptide Synthesis and Incorporation of the 3,4-Analogue in a Decapeptide Using Solid-Phase Synthesis
}

Isita Banerjee, Keshab Ch Ghosh, Emmanuel Oheix, Marion Jean, Jean-Valère Naubron, Marius Réglier, Olga Iranzo, Surajit Sinha

\section{To cite this version:}

Isita Banerjee, Keshab Ch Ghosh, Emmanuel Oheix, Marion Jean, Jean-Valère Naubron, et al.. Synthesis of Protected 3,4- and 2,3-Dimercaptophenylalanines as Building Blocks for Fmoc-Peptide Synthesis and Incorporation of the 3,4-Analogue in a Decapeptide Using Solid-Phase Synthesis. Journal of Organic Chemistry, 2021, 86 (3), pp.2210-2223. 10.1021/acs.joc.0c02359 . hal-03359178

\author{
HAL Id: hal-03359178 \\ https://hal.science/hal-03359178
}

Submitted on 30 Sep 2021

HAL is a multi-disciplinary open access archive for the deposit and dissemination of scientific research documents, whether they are published or not. The documents may come from teaching and research institutions in France or abroad, or from public or private research centers.
L'archive ouverte pluridisciplinaire HAL, est destinée au dépôt et à la diffusion de documents scientifiques de niveau recherche, publiés ou non, émanant des établissements d'enseignement et de recherche français ou étrangers, des laboratoires publics ou privés. 
Synthesis of protected 3,4- and 2,3-dimercaptophenylalanines as building blocks for Fmocpeptide synthesis and incorporation of the 3,4-analogue in a decapeptide using solid phase synthesis

Isita Banerjee, ${ }^{\ddagger}$ Keshab Ch Ghosh,,${ }^{\ddagger}$ Emmanuel Oheix,${ }^{\S}$ Marion Jean, ${ }^{\S}$ NAUBRON JeanValère," Marius Réglier, ${ }^{\S}$ Olga Iranzo, ${ }^{\S} *$ and Surajit Sinha ${ }^{\ddagger} * *$

* School of Applied and Interdisciplinary Sciences, Indian Association for the Cultivation of Science, Jadavpur, Kolkata 700 032, India, ocss5@iacs.res.in

$\S$ Aix Marseille Univ, CNRS, Centrale Marseille, iSm2, 13397 Marseille, France, *olga.iranzo@univ-amu.fr

": Aix Marseille Univ, CNRS, Centrale Marseille, FSCM-Spectropole, 13397 Marseille, France

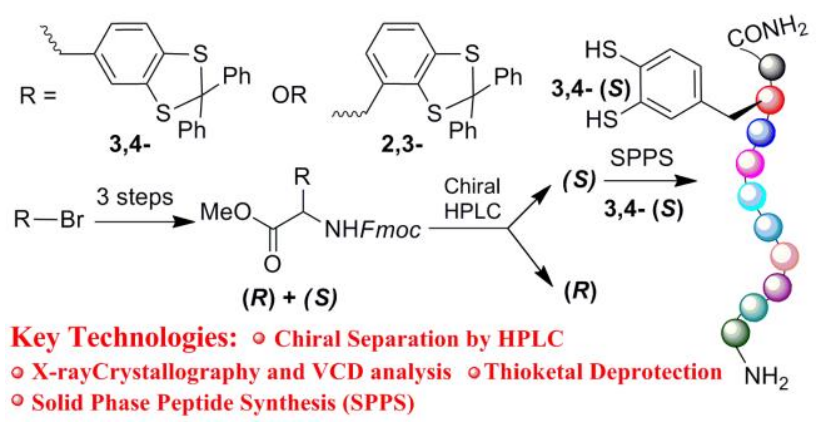

\section{ABSTRACT}

3,4- and 2,3-dimercaptophenylalanines have been synthesized for the first time by nucleophilic substitution of a protected aminomalonate on 3,4- and 2,3-dimercaptobenzylbromide derivatives. The dithiol functions were protected as thioketals and the key precursors, diphenylthioketalprotected dimercaptobenzylbromides, were synthesized via two distinct routes from either 
dihydroxy benzoates or toluene-3,4-dithiol. Racemic mixtures of the fully protected amino acids were separated by chiral HPLC into the corresponding enantiomers. The absolute configuration of both 3,4- and 2,3- analogues could be assigned based on X-ray crystallography and VCD/DFT measurements. Thioketal groups were deprotected upon reaction with mercury oxide and aqueous tetrafluoroboric acid followed by treatment with $\mathrm{H}_{2} \mathrm{~S}$ gas under an argon atmosphere to obtain the corresponding dimercapto amino acids. The optically pure L-Fmoc-protected 3,4analogue ( $S$ - enantiomer) was successfully incorporated into a decapeptide using standard solid phase peptide synthesis. Therefore, dithiolene functionalized peptides are now accessible from a simple synthetic procedure and this should afford new molecular tools for research into the catalysis, diagnostic, and nanotechnology fields.

\section{INTRODUCTION}

Cysteine is the only canonical amino acid having a thiol function and this allows this residue to play a unique role in protein functions (regulatory, catalytic or metal ion binding). ${ }^{1}$ The ability of the thiol group to form reversible disulfide bridges confers to cysteine a key role in the conformational structure of peptides or proteins. ${ }^{2}$ Over the past several decades, cysteine is also very often used in the thioester method for the chemical synthesis of peptides and proteins through native chemical ligation (NCL) as well as for their selective modification. ${ }^{3}$ On the other hand, the nucleophilicity of its conjugated base (cysteinate) endows proteins containing cysteines with special functional properties. Among them, the reactivity as a transient nucleophile in numerous enzymatic processes or as soft ligand having a high affinity for metals $(\mathrm{Fe}, \mathrm{Cu}, \mathrm{Hg}$, $\mathrm{Cd}, \mathrm{Zn}, \mathrm{Mo}, \mathrm{W} . .$.$) are certainly the most significant. { }^{1,4}$ Additionally, cysteine or cysteinecontaining peptides are useful in the generation of functionalized nanoparticles. ${ }^{4 \mathrm{~b}, 4 \mathrm{~d}-\mathrm{e}}$ 
Considering the importance of cysteine and the scarcity of thiol containing amino acids, the synthesis of new mercapto amino acid derivatives is highly desirable. Under these grounds, a number of non-canonical thiol-containing amino acids have been reported ${ }^{5}$ in which cysteine surrogates have been incorporated through the modification of naturally occurring amino acids with the main goal of overcoming the limitation of $\mathrm{N}$-terminal cysteine-mediated NCL for synthesizing large peptides/proteins. Surprisingly, there are very few reports in the case of dithiol-containing amino acids. ${ }^{6}$ Heinis et al. have prepared two L-4( $\left.R / S\right), 5$-dithionorvaline diastereoisomers as surrogate for the cysteine-cysteine fragment. ${ }^{6 a}$ This modification allows directing dithiol bond formation leading to specific peptide tertiary structures. Ghirlanda et al. have reported the preparation of a L-5,6-dithioleucine amino-acid, which was incorporated in a helical peptide to anchor a diiron hexacarbonyl cluster to a model helical peptide and mimic the hydrogenase active site for hydrogen production. $^{6 \mathrm{~b}}$ Wang et al. have synthesized dithiol functionalized L-tyrosine through the incorporation of 2-methylpropane-1,3-dithiol linker via the etherification of tyrosine $\mathrm{OH} .{ }^{6 c}$

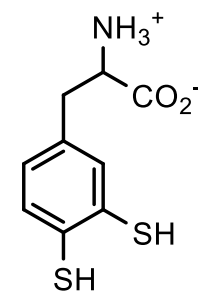

$F^{3,4-d t}$<smiles>[NH3+]C(Cc1cccc(S)c1S)C(=O)[O-]</smiles>

$F^{2,3-d t}$

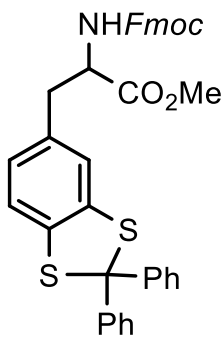

1a: 3,4

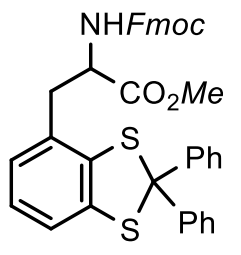

1b: 2,3

Figure 1. Structures of 3, 4- and 2, 3-dimercaptophenylalanine residues $\left(\mathbf{F}^{\mathbf{3}, \mathbf{4}-\mathbf{d t}}\right.$ and $\mathbf{F}^{\mathbf{2}, \mathbf{3}-\mathbf{d t})}$ and the fully protected amino-acids building blocks (1a and $\mathbf{1 b}$ ). 
Indeed, to the best of our knowledge, no amino-acid bearing the dithiolene (alkene-1,2dithiolate) function have been reported to date. These new building blocks can facilitate the introduction of dithiol groups and endow peptides/proteins with new structures and/or functionalities as previously mentioned. Sinha's group has focused on the synthesis of thiol and selenol-containing non-canonical amino acids for the past few years. ${ }^{7}$ In this context, we describe here the synthesis of suitably Fmoc-protected 3,4-dimercaptophenylalanine ( $\left.\mathbf{F}^{\mathbf{3}, 4-d t}\right)$ and 2,3dimercaptophenylalanine $\left(\mathbf{F}^{2,3-d t}\right)$ as building blocks to introduce the dithiolene group in peptides (Figure 1). The solid phase synthesis of a decapeptide containing the dithiolene functionalities is reported.

\section{RESULTS AND DISCUSSION}

\section{Pathways in the protection of dithiolene function}

Dithiolenes are reactive functions (e.g. nucleophile, reductant and metal binding) and finding a protecting group for the dithiolene function compatible with standard peptide synthesis protocols constituted our first priority. Acetamidomethyl (Acm) groups are commonly used in peptide synthesis to protect thiols ${ }^{8}$ or dithiols, ${ }^{6 a}$ and they constitute promising candidates. Moreover, the dithiol function can be regenerated upon treatment with excess of iodine. Using commercially available toluene-3,4-dithiol (2), we attempted the protection of dithiolene with Acm groups (Scheme 1, pathways a and b). Following a reported procedure, ${ }^{9}$ the deprotected compound (3) was obtained in a moderate $45 \%$ yield. When the reaction was carried out in the presence of TMSCl, ${ }^{10} \mathbf{3}$ was isolated in $48 \%$ yield. Discouraged by these initial results, we sought for alternatives. 
Dithiolenes functions can also be protected via $S$-acylation or formation of dithiocarbonates. In the first case, the conventional deprotection involves the use of highly basic and poorly selective alkoxide. In contrast, dithiocarbonate can be readily converted to the related dithiols by hydrolysis. Therefore, using the second alternative, the compound 4 was obtained in $92 \%$ yield upon reacting 2 with 1,1'-carbonyldiimidazole (Scheme 1, pathway c).

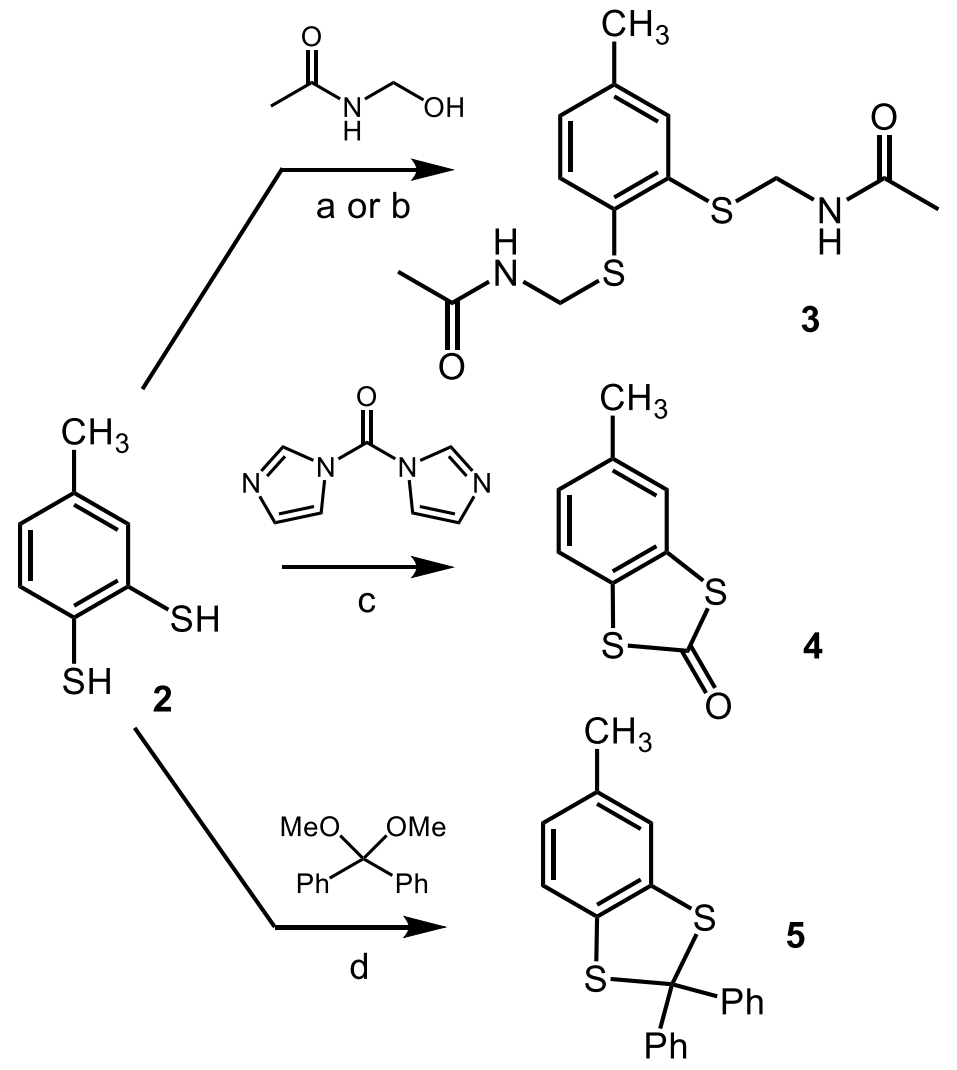

Scheme 1. Protection of aryldithiol: Reagents and conditions: Pathway a) $N$ (hydroxymethyl)acetamide (3.2 equiv), conc. $\mathrm{HCl}, \mathrm{MeOH}, \mathrm{RT}, 20 \mathrm{~h}$ : 45\%; Pathway b) $\mathrm{N}$ (hydroxymethyl)acetamide (3.2 equiv), TMSCl (2 equiv), THF, RT, 16 h: 48\%; Pathway c) Carbonyldiimidazole (1.2 equiv), THF, RT, 18 h, 92\%; Pathway d) $\mathrm{Ph}_{2}(\mathrm{OMe})_{2}$ (1.2 equiv), pTSA (10 mol\%), Toluene, $12 \mathrm{~h}$, reflux, $98 \%$. 
We suspected that the dithiocarbonate function might be labile in basic conditions, therefore, compound 4 was treated with $20 \%$ piperidine in DMF, a mixture conventionally used to deprotect Fmoc-protected amines in Fmoc- peptide chemistry. After $1 \mathrm{~h}$ reaction and drying in vacuo, ${ }^{1} \mathrm{H}$ NMR analysis of the crude mixture indicated the presence of several products. Therefore, dithiocarbonates have poor compatibility with Fmoc chemistry and we sought an alternative protection strategy.

Dithiol compounds are used to protect aldehyde or ketones as thioketals. ${ }^{11}$ Looking from the opposite perspective, it might be possible to protect dithiolene as thioketal upon reaction with a suitable aldehyde or ketone, provided suitable deprotection conditions can be found. Surprisingly, there is no reported method for aryldithiols protection as thioacetal or thioketal. Since we were interested on limiting the number of chiral centres in the target amino acid, we decided to use a symmetrical ketone. Following a reported thioketalization method, ${ }^{12}$ we tried to prepare compound 5 by reacting 2 with benzophenone in the presence of catalytic amount of iodine but the expected compound $\mathbf{5}$ was obtained in poor yield (38\%). A slightly higher yield (45\%) was obtained for the acid-catalysed ( $p$-toluenesulfonic acid) ketalization in dry toluene after $15 \mathrm{~h}$ reflux. Different conditions $\left(\mathrm{BF}_{3} . \mathrm{OEt}_{2}, 53 \%\right.$ and $\left.\mathrm{FeCl}_{3}, 57 \%\right)$ (Table S1) were exploited but the yield has not been improved. In contrast, replacing benzophenone for its dimethyl ketal derivative ${ }^{13}$ afforded compound 5 in $98 \%$ yield (Scheme 1, pathway d). Following this procedure, dithiolenes can be conveniently protected as thioketals and, importantly, dithiolene functions can be regenerated selectively.

\section{Synthesis of racemic mixtures $1 \mathrm{a}$ and $\mathbf{1 b}$.}


The specific aim of this work is to prepare $\mathbf{F}^{\mathbf{3}, \mathbf{4}-\mathbf{d t}}$ and $\mathbf{F}^{\mathbf{2}, \mathbf{3}-\mathrm{dt}}$ as suitable building blocks for Fmocpeptide synthesis. Towards this goal, the target molecules, $\mathbf{1 a}$ and $\mathbf{1 b}$, will include methyl esters protected carboxylates, Fmoc-protected amines, and dithiol side-chains protected as thioketals. Our initial approaches towards the asymmetric synthesis of $\mathbf{F}^{\mathbf{3}, \mathbf{4}-\mathrm{dt}}$ from L-DOPA (Scheme S1) and $\mathbf{F}^{\mathbf{2}, 3-d t}$ based on the Negishi coupling between dimercapto-iodobenzene and $(R)$-methyl 2((tert-butyloxycarbonyl)amino)-3-iodopropanoate (Scheme S2) were not successful and encountered a number of problems while handling the reactions in the presence of dithiol. Therefore, we focused on obtaining the racemic mixtures. Our retrosynthetic pathway towards racemic compounds $\mathbf{1 a}$ and $\mathbf{1 b}$ is in Scheme 2. The coupling of $N$-protected aminodiethylmalonate with suitably dithiol-protected dimercaptobenzylbromide shall afford $6 \mathbf{6}$ and $\mathbf{6 b}$, which upon hydrolysis and reprotection lead to $\mathbf{1 a}$ and $\mathbf{1 b}$. The key precursors dimercaptobenzylbromides $(\mathbf{7 a} / \mathbf{7 b})$ could be synthesized from dimercapto benzoates $(\mathbf{8 a} / \mathbf{8 b})$, which, in turn, can be prepared from the corresponding dihydroxy benzoates (9a/9b) by Newman-Kwart rearrangement $(\mathrm{NKR})^{14}$ (Scheme 2, route A). In this reaction, intramolecular migration of O-thiocarbamates at high temperature leads to $S$-thiocarbamates. ${ }^{14}$ Alternatively, 3,4-dimercaptobenzylbromide (7a) can be prepared directly from toluene-3,4-dithiol 2 (Scheme 2 , route $\mathrm{B})$. 


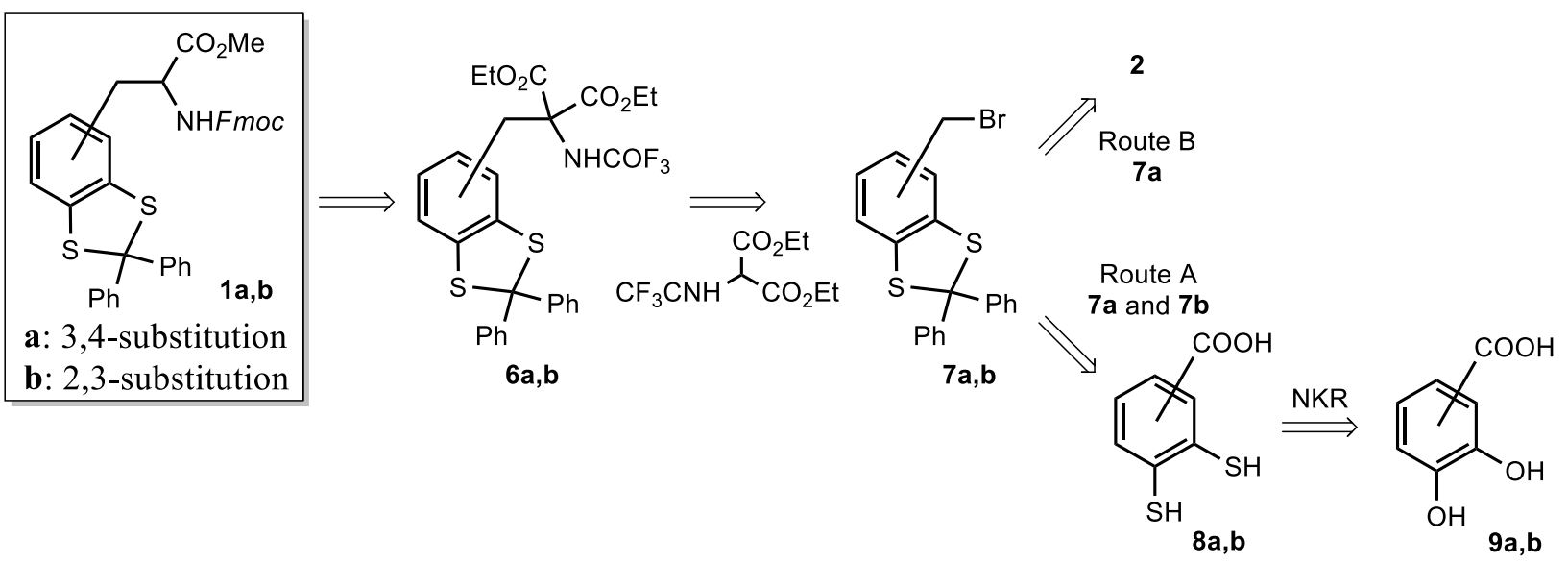

Scheme 2. Retrosynthetic route towards racemic compounds $\mathbf{1 a}$ and $\mathbf{1 b .}$

Starting from affordable substrates $\mathbf{9 a}$ and $\mathbf{9 b}$, compounds $\mathbf{7 a}$ and $\mathbf{7 b}$ were obtained in 8 steps in $21 \%$ (7a) and $18 \%$ (7b) overall yields, respectively (Scheme 3, route A). Dimercaptobenzoic acids $\mathbf{8 a}$ and $8 \mathbf{b}$ were synthesized from the corresponding 3,4- and 2,3-dihydroxybenzoic acids $(\mathbf{9 a}, \mathbf{b})$, respectively, via the formation of NKR products, following the previously reported procedures (Scheme S3). ${ }^{15} \mathbf{1 0 a}$ and $\mathbf{1 0 b}$ were hydrolyzed by $\mathrm{NaOH}$ solution to obtain dimercaptobenzoic acids $\mathbf{8} \mathbf{a}^{15 b}$ and $\mathbf{8} \mathbf{b}^{15}$ which were then directly used for dithiolene protection as thioketals, to afford 11a and $\mathbf{1 1 b}$, respectively (Scheme 3). 

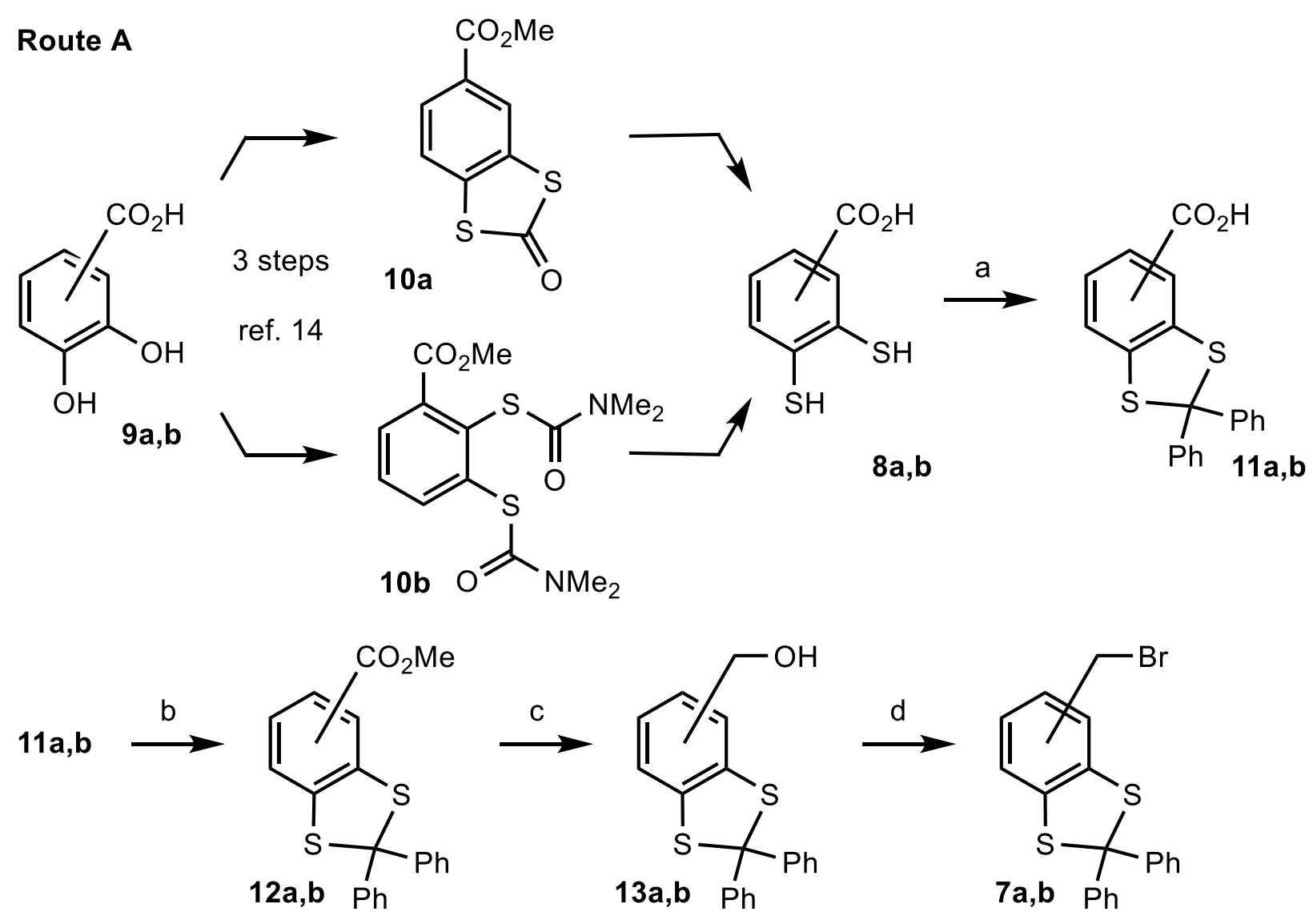

Route B
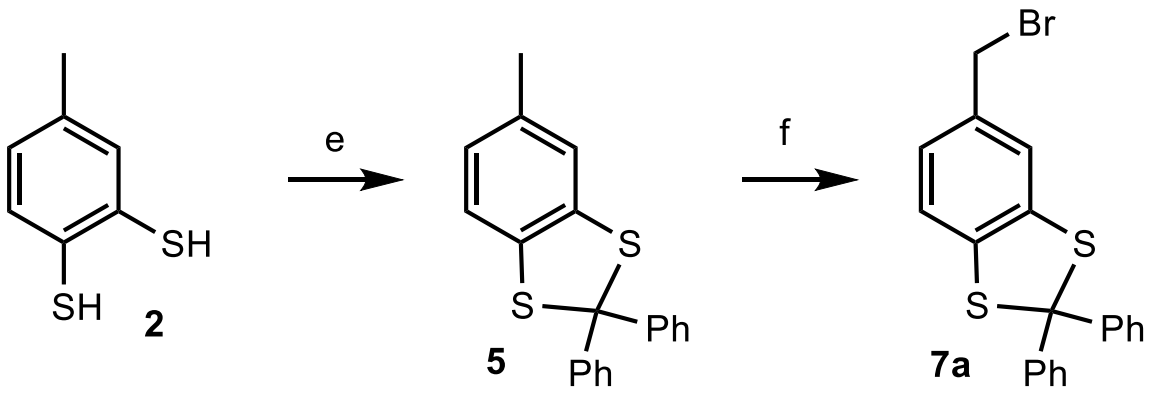

Scheme 3. Preparation of compounds $7 \mathbf{a}$ and $\mathbf{7 b}$, reagents and conditions: a) $\mathrm{Ph}_{2}(\mathrm{OMe})_{2}(1.2$ equiv), p-TSA (10 mol\%), toluene, reflux, 12 h, 11a: 84\%, 11b: $81 \%$ (from 10a/10b); b) $\mathrm{K}_{2} \mathrm{CO}_{3}$ (2 equiv), $\mathrm{CH}_{3} \mathrm{I}$ (4 equiv), DMF, $0^{\circ} \mathrm{C}$ to $\mathrm{RT}, 12 \mathrm{~h}, \mathbf{1 2 a :} 84 \%, 12 \mathrm{~b}: 81 \%$; c) $\mathrm{AlCl}_{3}$ (1.5 equiv), $\mathrm{LiAlH}_{4}$ (3.8 equiv), $\mathrm{Et}_{2} \mathrm{O}, 0{ }^{\circ} \mathrm{C}, 5 \mathrm{~min}, \mathbf{1 3 a}: 92 \%, \mathbf{1 3 b}: 91 \%$; d) $\mathrm{PBr}_{3}$ (1 equiv), $\mathrm{Et}_{2} \mathrm{O}, 0{ }^{\circ} \mathrm{C}$ to $\mathrm{RT}$, 4 h, 7a: 85\%, 7b: 85\%; e) $\mathrm{Ph}_{2}(\mathrm{OMe})_{2}$ (1.2 equiv), $p$-TSA (10 mol\%), Toluene, 12 h, refluxed, 5: $98 \%$; f) NBS (1.1 equiv), $\mathrm{CH}_{2} \mathrm{Cl}_{2}, 1.5 \mathrm{~h}$, refluxed, $7 \mathbf{a}: 65 \%$. 
The dimercaptobenzyl bromides $\mathbf{7 a}$ and $\mathbf{7 b}$ were obtained in three steps via the formation of the esters $(\mathbf{1 2 a} / \mathbf{1 2 b})$ and alcohol derivatives $(\mathbf{1 3 a} \mathbf{a} \mathbf{1 3 b})$ (Scheme 3). The methyl benzoates 12a and 12b were prepared using standard method. The optimal ester reduction procedure involved insitu preparation of $\mathrm{AlH}_{3}$ and afforded the desired alcohols $(\mathbf{1 3 a} / \mathbf{1 3 b})$ at $0^{\circ} \mathrm{C}$ within $10 \mathrm{~min}$ in quantitative yields. The pure reduction products were not obtained when $\mathrm{LiAlH}_{4}$ or $\mathrm{LiBH}_{4}$ was used. Finally, $\mathrm{PBr}_{3}$-mediated bromination of $\mathbf{1 3 a}$ and $\mathbf{1 3 b}$ was achieved in anhydrous diethyl ether at $0{ }^{\circ} \mathrm{C}$ for $4 \mathrm{~h}$ affording $\mathbf{7 a}$ and $\mathbf{7 b}$ in $85 \%$ yields (Scheme 3 , route A). The solvent has an important role in this reaction when the reaction was performed in dichloromethane, 7a was obtained whereas $\mathbf{7 b}$ got decomposed in the reaction mixture. $\mathrm{CBr}_{4} / \mathrm{PPh}_{3}$ led to the formation of a number of unidentified products. As an alternative, compound 7a could be obtained in two steps and $64 \%$ overall yield starting from the commercially available compound $\mathbf{2}$ (Scheme 3, route B). The first step involved the previously described protection of $\mathbf{2}$ as $\mathbf{5}$ and the second step involved the bromination with $\mathrm{N}$-bromosuccinimide. ${ }^{16}$ The bromination of Acm-protected $\mathbf{3}$ was also attempted under similar conditions, unfortunately we ended up with a large number of unidentified products. During the preparation, crystals of $\mathbf{7 a}$ and $\mathbf{7 b}$ suitable for X-ray diffraction were obtained and the structure of these compounds are reported (Figure S1, Tables S2, S3).

For the next step, different conditions were screened in order to optimize the coupling of dimercaptobenzyl bromides with malonate esters in the presence of base (Table 1). Different malonates were tested, including acetamido (14), Boc-protected (15) and trifluoroacetamido malonates (16). Compounds 15 and 16 were synthesized from diethyl(amino)malonate hydrochloride which was prepared using the literature procedure. ${ }^{17}$ The reaction between $7 \mathbf{a}$ and 14 in the presence of $\mathrm{NaH}$ run at room temperature (RT) for $12 \mathrm{~h}$ in dry DMF led to the desired 
product 17a in $65 \%$ yield (Table 1, entry 1). However, we were unable to obtain the amine deprotected product through the hydrolysis of acetamide bond in the presence of $\mathrm{NaOH}$ in water:THF mixture. Hence, we used malonates $\mathbf{1 5}$ and 16, where Boc group can be removed under 20\% TFA in DCM and trifluoroacetamide can be removed in the presence of $\mathrm{LiOH}$ in water:THF mixture. The reaction of $\mathbf{7 a}$ with diethyl(Boc-amino)malonate $\mathbf{1 5}$ was first attempted at $\mathrm{RT}$ for $12 \mathrm{~h}$ in the presence of $\mathrm{NaH}$ and led to the formation of several unidentified products and unreacted starting material (Table 1, entry 2). No quantitative yield of 18a could be attained upon increasing the temperature or replacing $\mathrm{NaH}$ for $\mathrm{NaOEt}$ or $\mathrm{Cs}_{2} \mathrm{CO}_{3}$ (Table 1, entries 3-5). ${ }^{18}$ In contrast, reacting $\mathbf{7 a}$ with $\mathbf{1 6}$ at $\mathrm{RT}$ in dry DMF containing $\mathrm{NaH}$, led to the formation of compound 6a in $40 \%$ yield (Table 1, entry 6). The optimal reaction time was found to be $6 \mathrm{~h}$ and led to $\mathbf{6 a}$ in $82 \%$ yield (Table 1, entry 7). Following these conditions, the 2,3- substrate $\mathbf{6 b}$ was synthesized in $75 \%$ yield (Table 1, entry 8 ).

Table 1. Standardization of reaction conditions.

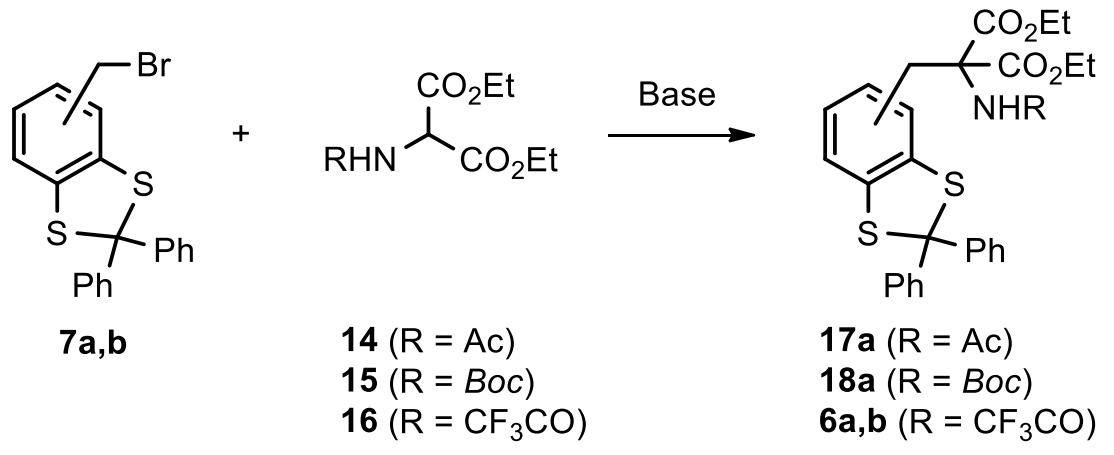

\begin{tabular}{cccccccc}
\hline Entry & SM & Re & Base & S & T & t & Y \\
\hline 1 & $\mathbf{7 a}$ & $\mathbf{1 4}$ & NaH & DMF & RT & $12 \mathrm{~h}$ & 65 \\
2 & $\mathbf{7 a}$ & $\mathbf{1 5}$ & NaH & DMF & RT & $12 \mathrm{~h}$ & 32
\end{tabular}




\begin{tabular}{cccccccr}
3 & $\mathbf{7 a}$ & $\mathbf{1 5}$ & $\mathrm{NaH}$ & $\mathrm{DMF}$ & $70^{\circ} \mathrm{C}^{*}$ & $12 \mathrm{~h}$ & -- \\
4 & $\mathbf{7 a}$ & $\mathbf{1 5}$ & $\mathrm{NaOEt}$ & $\mathrm{EtOH}$ & $0{ }^{\circ} \mathrm{C}$ & $3 \mathrm{~h}$ & -- \\
5 & $\mathbf{7 a}$ & $\mathbf{1 5}$ & $\mathrm{Cs}_{2} \mathrm{CO}_{3}$ & $\mathrm{DMF}$ & $70^{\circ} \mathrm{C}^{*}$ & $12 \mathrm{~h}$ & -- \\
6 & $\mathbf{7 a}$ & $\mathbf{1 6}$ & $\mathrm{NaH}$ & $\mathrm{DMF}$ & $\mathrm{RT}$ & $12 \mathrm{~h}$ & 40 \\
7 & $\mathbf{7 a}$ & $\mathbf{1 6}$ & $\mathrm{NaH}$ & $\mathrm{DMF}$ & $\mathrm{RT}$ & $6 \mathrm{~h}$ & 82 \\
8 & $\mathbf{7 b}$ & $\mathbf{1 6}$ & $\mathrm{NaH}$ & $\mathrm{DMF}$ & $\mathrm{RT}$ & $6 \mathrm{~h}$ & 75 \\
\hline
\end{tabular}

Reaction conditions: Substrate $(1.0 \mathrm{mmol})$, malonate $(1.0 \mathrm{mmol})$, base $(1.2 \mathrm{mmol})$, dry solvent $(5$ $\mathrm{ml}$ ) were added at $0^{\circ} \mathrm{C}$ (except for $*$ ) under inert atmosphere and allow to warm to the reaction temperature; $\mathrm{SM}=$ starting material; $\mathrm{Re}=$ reagent; $\mathrm{S}=$ solvent; $\mathrm{T}=$ reaction temperature; $\mathrm{t}=$ reaction time; $\mathrm{Y}=$ Yields of isolated pure products in $\%$ (--- indicates that the reaction led to several unidentified product and/or starting material).

Then, the hydrolysis of ester function, decarboxylation reaction and hydrolysis of trifluoroacetamide group were performed in one-pot following our previously reported procedure. ${ }^{19}$ Accordingly, compounds $6 \mathbf{6}$ and $\mathbf{6 b}$ were treated with aqueous $\mathrm{LiOH}$ solution in THF (1:1) at $70^{\circ} \mathrm{C}$ for $12 \mathrm{~h}$. The crude products were directly reacted with Fmoc-OSu ester in standard conditions to isolate the Fmoc-protected amino acids 19a and 19b in 75 and $72 \%$ yields, respectively. Treatment with $\mathrm{MeI}$ at RT for $12 \mathrm{~h}$ in the presence of $\mathrm{K}_{2} \mathrm{CO}_{3}$ afforded the methyl esters $\mathbf{1 a}$ and $\mathbf{1 b}$ in 78 and $77 \%$ yields, respectively (Scheme 4). The free-acids 19a and 19b can be recovered upon treatment with $\mathrm{CaCl}_{2}$ and $\mathrm{LiOH}$ in a mixture of water, isopropanol and tetrahydrofuran. ${ }^{20}$ 


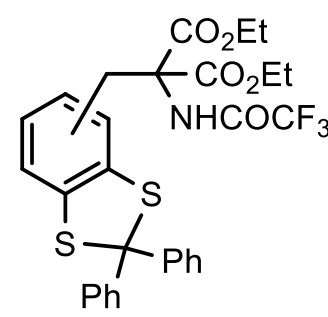

$6 a, b$

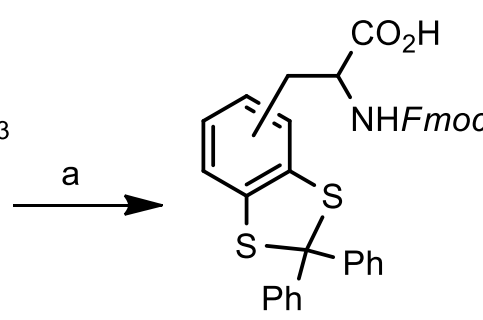

$19 a, b$
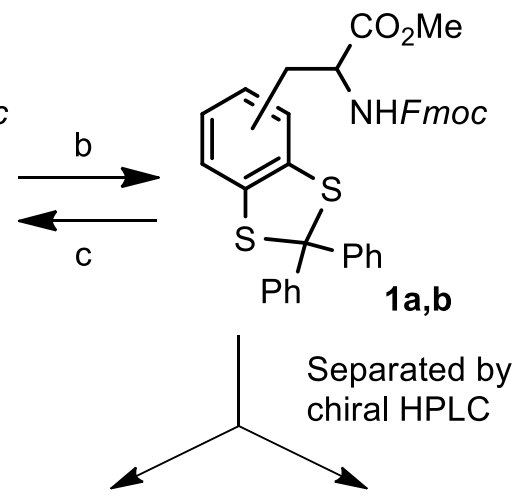

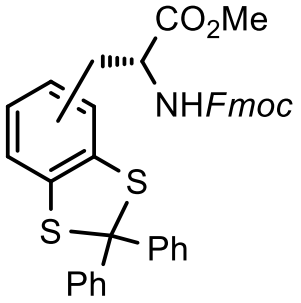

1a,b-R

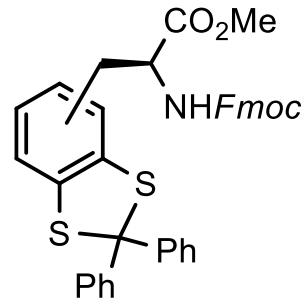

$1 a, b-S$

Scheme 4. Synthesis of protected dimercaptophenylalanines 1a and 1b: Reagents and conditions: a) i) $\mathrm{LiOH}_{2} \mathrm{H}_{2} \mathrm{O}$ (12 equiv), $\mathrm{H}_{2} \mathrm{O}$-THF (1:1), $70{ }^{\circ} \mathrm{C}, 12 \mathrm{~h}$; ii) $\mathrm{NaHCO}_{3}, F m o c-\mathrm{OSu}(2$ equiv), Dioxane- $\mathrm{H}_{2} \mathrm{O}, \mathrm{RT}, 12$ h, 19a: 75\%, 19b: 72\%; b) $\mathrm{CH}_{3} \mathrm{I}$ (4 equiv), $\mathrm{K}_{2} \mathrm{CO}_{3}$ (2 equiv), DMF, RT, 12 h, 1a: 78\%, 1b: 77\%; c) $\mathrm{CaCl}_{2}$ (16 equiv), $\mathrm{LiOH}_{\mathrm{H}} \mathrm{O}$ (4 equiv), Isopropanol / THF/ $\mathrm{H}_{2} \mathrm{O}(3: 1: 1.5), 2.5$ h, 19a: $98 \%, 19 b: 90 \%$.

\section{Chiral separation and assignment of absolute configuration}

The racemic mixtures contained $\sim 10 \%$ side-products, which were either removed before (1a) or during the chiral separation (1b). The racemic mixtures were then eluted isocratically with heptane/isopropanol/dichloromethane mixtures on an analytical Chiralpak IF column. Both chromatograms display two peaks with similar integral values (Figure 2 and Figure S2 for 1b). Using these conditions, the fractions were separated on a preparative Chiralpak IF column and individual enantiomers (enantiomeric excess > 99\%) were characterized by electronic circular 
dichroism (Figures S3 for 1a, S4 for 1b), and optical rotation measurements (Tables S4 for 1a, S5 for 1b).

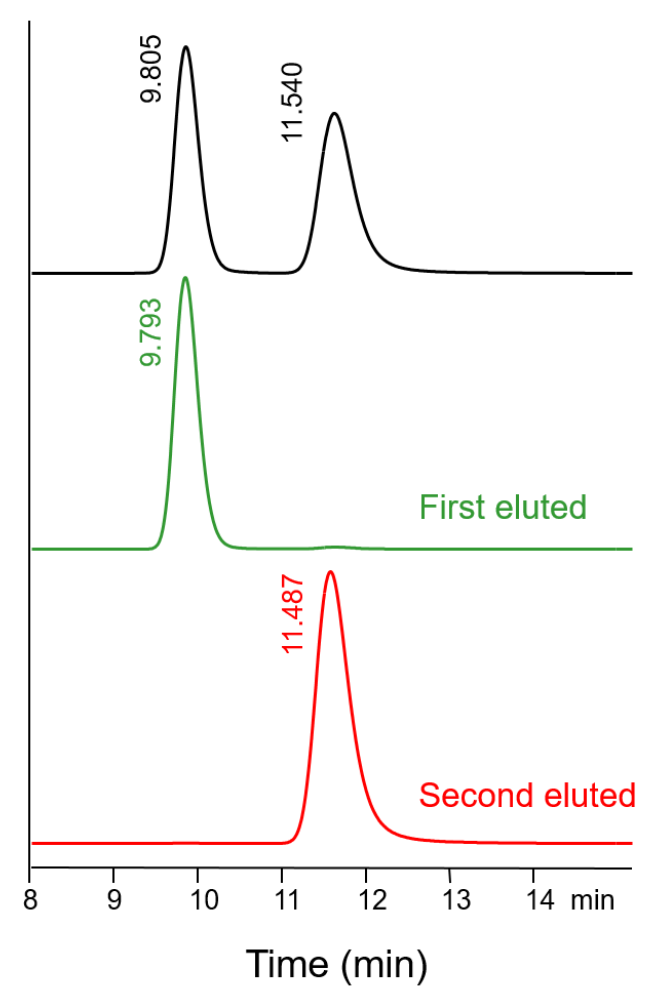

Figure 2. HPLC chromatogram (detection at $254 \mathrm{~nm}, 1 \mathrm{~mL} / \mathrm{min}$ ) recorded upon isocratic elution with heptane/isopropanol/dichloromethane (80/10/10) on analytical Chiralpak IF of (Top) racemic mixture of compound 1a, (middle) purified enantiomer 1a- $\boldsymbol{R}$, (bottom) purified enantiomer 1a-S.

In the case of 1a, thin-needles of the enantiomer eluting first in HPLC were obtained and X-ray diffraction measurements allowed to determine the structure and the absolute configuration as $(R)$ (Figures 3, S5, S6, Table S6). Hence, 1a- $R$ defines the compound eluting at 9.8 min in chiral HPLC (Figure 2). The absolute configuration assignment established by X-ray diffraction was 
consolidated by a Vibrational circular dichroism (VCD) analysis. The VCD spectrum calculated (DFT) for the $(R)$ enantiomer is in very good agreement with the measured spectrum of the first eluted enantiomer. The VCD spectrum of the first and second eluted enantiomers have been recorded in $\mathrm{CD}_{2} \mathrm{Cl}_{2}$ and compared to the calculated averaged spectrum of the $\mathbf{1 a}-\boldsymbol{R}$ enantiomer (Figure 3). Calculations were performed using Density Functional Theory (DFT) with the B3LYP functional and with the 6-311G(d,p) basis set. The polarized continuum model SMD has been used for the solvent effects. The conformational flexibility of 1a has been studied: 9 conformations with Boltzmann population higher than $3 \%$ have been retained to build the averaged VCD spectrum (Figures S7-S9, Table S7). 

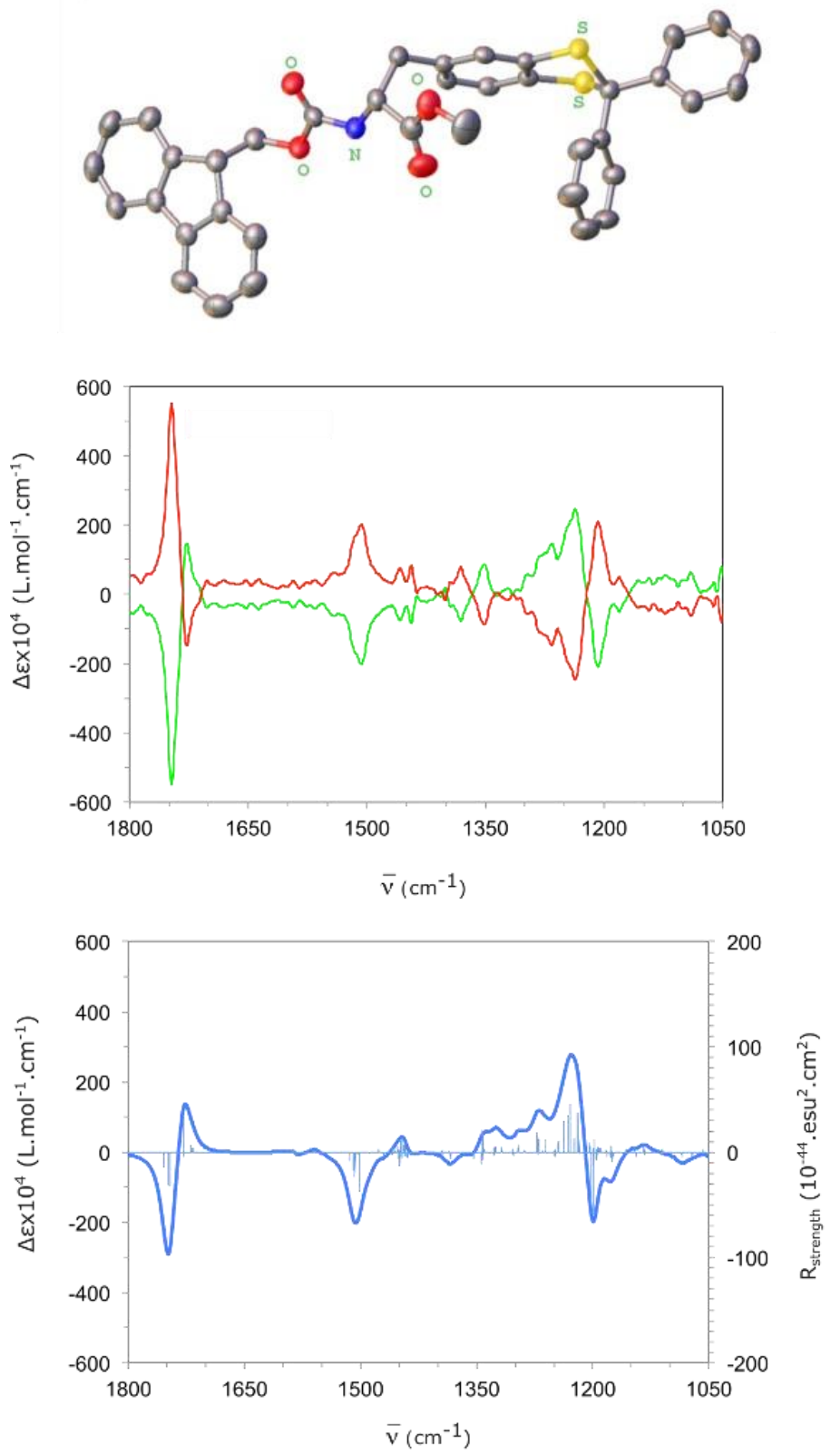

Figure 3. (Top) ORTEP representation of the X-ray structure of the first eluted enantiomer of compound 1a with 50\% probability thermal ellipsoids and partial atom labeling scheme (Hydrogen atoms are omitted for clarity). (Middle) Experimental VCD spectra recorded in $\mathrm{CD}_{2} \mathrm{Cl}_{2}$ at $298 \mathrm{~K}$ of $\left(1^{\text {st }}\right.$ eluted)-1a (green) and ( $2^{\text {nd }}$ eluted)-1a (red). (Bottom) Calculated averaged VCD spectrum for 1a- $\boldsymbol{R}$ (dark blue). 
As discussed earlier for $\mathbf{1 a}$, the racemic mixture of $\mathbf{1 b}$ was separated into the corresponding enantiomers (1b-R and $\mathbf{1 b}-\boldsymbol{S}$ ) by chiral HPLC on chiralpak ID (Figure S2). Fractions of two enantiomers eluting at 5.51 and 6.48 min were collected and characterized by optical rotations (Table S5) and circular dichroism (Figure S4). As for 1a, the VCD was used to establish unambiguously the absolute configuration $(R)$ of the first eluted enantiomer of $\mathbf{1 b}$ (Figures S10-S11, Table S8).

In order to use these building blocks in peptide synthesis, the acid function must be deprotected. For this, compound $\mathbf{1 a}-\boldsymbol{R}$ and $\mathbf{1 a}-\mathbf{S}$ were individually treated with $\mathrm{CaCl}_{2}$ and $\mathrm{LiOH}$ solution ${ }^{20}$ to afford 19a- $\boldsymbol{R}$ and 19a-S in $98 \%$ and $90 \%$ yields, respectively following the protocol of racemic mixtures reported in scheme 4. Analytical chiral HPLC confirmed that the deprotection conditions did not lead to racemisation as the enantiomeric excess of both $19 \mathbf{a}-\boldsymbol{R}$ and $19 \mathbf{a}-\boldsymbol{S}$ was $>99 \%$ (Figure S12).

\section{Deprotection of the dithiolene function via thioketal hydrolysis:}

The dithiol side-chain deprotection is best achieved via thioketals hydrolysis. In order to drive the reaction to completion, common methods involve the consumption of the dithiols sideproduct as it forms (via alkylation, oxidation or metal complexation). ${ }^{21}$ In our case, the dithiol is the desired product, hence a two-step process was used: (i) treatment with $\mathrm{Hg}^{\mathrm{II}}$ and acid leading to the formation of the $\mathrm{Hg}^{\mathrm{II}}$ complex; (ii) removal of the $\mathrm{Hg}^{\mathrm{II}}$ ion using excess of $\mathrm{H}_{2} \mathrm{~S}$. Following a reported procedure, ${ }^{22}$ deprotection of racemic amino acids $\mathbf{1 a}$ and $\mathbf{1 b}$ was attempted with $\mathrm{HgCl}_{2}$ in acetonitrile:water or in pure trifluoroacetic acid but no deprotection was observed as TLC monitoring indicated that no benzophenone side-product was formed. The replacement of mercury for less toxic reagents such as $\mathrm{AgNO}_{3},{ }^{22} \mathrm{AgNO}_{2},{ }^{22}$ or $\mathrm{Na} /$ naphthalene ${ }^{23}$ did not give any 
desired product. Treatment with triethylsilane in $50 \% \mathrm{TFA}^{24}$ gave a trace amount of product. Treatment with $\mathrm{HgO}$ afforded partial conversion in acetonitrile:water or in trifluoroacetic acid:THF. Complete deprotection was obtained (monitored by TLC) using $\mathrm{HgO}$ and $35 \%$ aqueous $\mathrm{HBF}_{4}$ in THF leading to the mercury complex $\mathbf{2 0}$ of the corresponding amino acids $\mathbf{1 a}$ and 1b (Scheme 5). Successive trituration of the crude mixture with water followed by petroleum-ether to remove $\mathrm{HBF}_{4}$ and benzophenone, respectively gave rise to the $\mathrm{Hg}$-complex $\mathbf{2 0}$ as a pale yellow precipitate. Next, $\mathrm{H}_{2} \mathrm{~S}$ gas was flown into a suspension of 20 in EtOAc under argon atmosphere (maintained by Schlenk line) and successfully isolated the desired products 21a and 21b after centrifugation. We could not isolate the product when the reaction was carried out under Ar balloon. It is worth to mention here that isolation of dimercaptopropanol from $\mathrm{Hg}$ complex by the decomposition of $\mathrm{H}_{2} \mathrm{~S}(\mathrm{~g})$ was not possible earlier perhaps, presence of oxygen may have substantial effect in the isolation of free dithiol. ${ }^{25}$ As X-ray photo electron spectroscopy (XPS) is a useful technique for the detection of inorganic elements, we performed XPS analysis of the amino acids 21a and 21b. The core level spectra shown two peaks with the highest relative intensities at binding energies 163.5 and $164.6 \mathrm{eV}$ which correspond to $\mathrm{S} 2 \mathrm{p}_{3 / 2}$ and $\mathrm{S} 2 \mathrm{p}_{1 / 2}$ core lines, respectively (Figures $\mathrm{S} 13, \mathrm{~S} 14$ ). These values were in good agreement with the reported data of sulphur. ${ }^{26}$ However, no band was observed for the $\mathrm{Hg} 4 \mathrm{~d}$ core level in the spectral window 383-353 eV, consistent with the absence of Hg-containing impurities..$^{26,27}$ Since the absorption length of core level electrons depends on the kinetic energy, $\mathrm{Hg} 4 \mathrm{~d}$ level is preferred over $\mathrm{Hg} 4 \mathrm{f}$ level for component analysis. The presence of free $-\mathrm{SH}$ was confirmed by IR spectroscopy, where peaks at $2555 \mathrm{~cm}^{-1}$ for 3,4- amino acid (21a) and $2549 \mathrm{~cm}^{-1}$ for $2,3-$ amino acid (21b) were obtained, and further characterized by NMR and HRMS. In the case of 
3,4-dimercaptophenylalanine derivative 21a, sometimes we observed a mass of $949.1724[\mathrm{M}+$ $\mathrm{Na}]^{+}$corresponding to dimerization product as a single peak in HRMS analysis (Supporting Inf.).

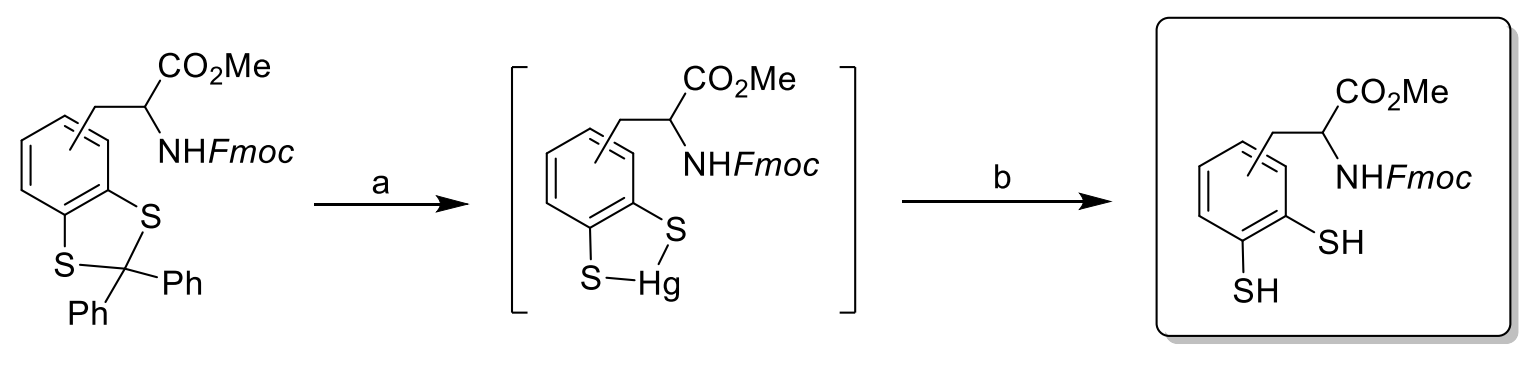

$1 a, b$

$20 a, b$

21a,b

Scheme 5. Synthesis of dimercaptophenylalanines: Reagents and conditions: a) $\mathrm{HgO}$ (1.5 equiv), $\mathrm{HBF}_{4} 35$ wt. \% in $\mathrm{H}_{2} \mathrm{O}$ (6.8 equiv), THF, RT; b) $\mathrm{H}_{2} \mathrm{~S}$ (g), EtOAc, RT, 4h, Ar maintained by Schlenck line, 21a: $44 \%, \mathbf{2 1 b}: 43 \%$.

\section{Solid-phase peptide synthesis of a decapeptide containing L-Phe ${ }^{3,4-d t}\left(=\mathrm{L}-\mathrm{F}^{3,4-d t}\right)$}

In order to test the applicability of the noncanonical amino-acid L-Phe $\mathbf{e}^{\mathbf{3 , - d t}}$ in solid-phase peptide synthesis, we prepared the decapeptide $\mathrm{H}_{2} \mathrm{~N}$-Tyr-Leu-Ser-Ala-Phe-His-Ala-Glu-Phe ${ }^{3,4-d t}$-Gly$\mathrm{CONH}_{2}$ bearing only L-residues and different side chain functionalities. At first, sequence $\mathrm{H}_{2} \mathrm{~N}$ $\operatorname{Tyr}\left(\mathrm{O}^{t} \mathrm{Bu}\right)-\mathrm{Leu}-\mathrm{Ser}\left(\mathrm{O}^{\mathrm{t}} \mathrm{Bu}\right)$-Ala-Phe-His(Trt)-Ala-Glu$\left(\mathrm{O}^{t} \mathrm{Bu}\right)-\mathrm{Phe}^{3,4-\mathrm{dt}}\left(\mathrm{CPh}_{2}\right)$-Gly-resin $\quad$ was assembled on rink amide resin by mixed manual and automated solid-phase peptide synthesis using standard protocols (see experimental section). In this case, the non-canonical amino-acid 19a-S was incorporated by manual synthesis in the $2^{\text {nd }}$ position starting from C-terminus in order to test its stability during 8 successive amino-acid couplings (Scheme 6). After final Fmoc deprotection, the decapeptide $\mathbf{2 2}$ was simultaneously deprotected (except for the thioketal group) and cleaved from the resin to obtain $\mathbf{2 3}$. Using the method previously described for $\mathbf{2 1 a}$ and $\mathbf{2 1 b}$, the thioketal function was hydrolyzed to obtain the deprotected decapeptide $\mathbf{2 4}$ (Scheme 6). In 
order to eliminate any $\mathrm{Hg}$ impurities, decapeptide $\mathbf{2 4}$ was then treated with dithiothreitol (DTT, 5 equiv) and passed through dialysis bag for 48 hours. The absence of $\mathrm{Hg}$ was confirmed by XPS analysis, displaying no peak for $\mathrm{Hg} 4 \mathrm{~d}$ core level in the range 383-350 eV (Figure S15). Peptide (24) was characterized by MALDI-TOF and its purity (>95\%) was determined by HPLC using SPOLAR C18 S5 column (Figure S16). In IR spectroscopy a peak at $2535 \mathrm{~cm}^{-1}$ was observed which strongly suggested the presence of free $-\mathrm{SH}$ group. In any case, the preparation of the peptide $\mathbf{2 3}$ demonstrated that the protection scheme described herein is compatible with standard solid-phase peptide synthesis and the dithioketal deprotection could be selectively achieved in solution affording $\mathbf{2 4}$ as free dithiolene-containing peptide. Before the treatment with DTT, the crude decapeptide was subjected to MALDI TOF mass analysis and four peaks were found at $\mathrm{m} / \mathrm{z}$ values of 1227.613 (calcd 1226.4739) and 1244.351 (calcd 1242.4478) corresponding to [M $+\mathrm{Na}]^{+}$and $[\mathrm{M}+\mathrm{K}]^{+}$, respectively. The other two masses present at $\mathrm{m} / \mathrm{z}$ values of 1259.337 (calcd 1258.4460) and 1275.481 (calcd 1274.4199) corresponded to persulfides [M - H + SH + $\mathrm{Na}]^{+}$and $[\mathrm{M}-\mathrm{H}+\mathrm{SH}+\mathrm{K}]^{+}$, respectively as expected based on the literature reports. ${ }^{28}$ DTTmediated persulfide reduction gave the desired product $\mathbf{2 4}$. 


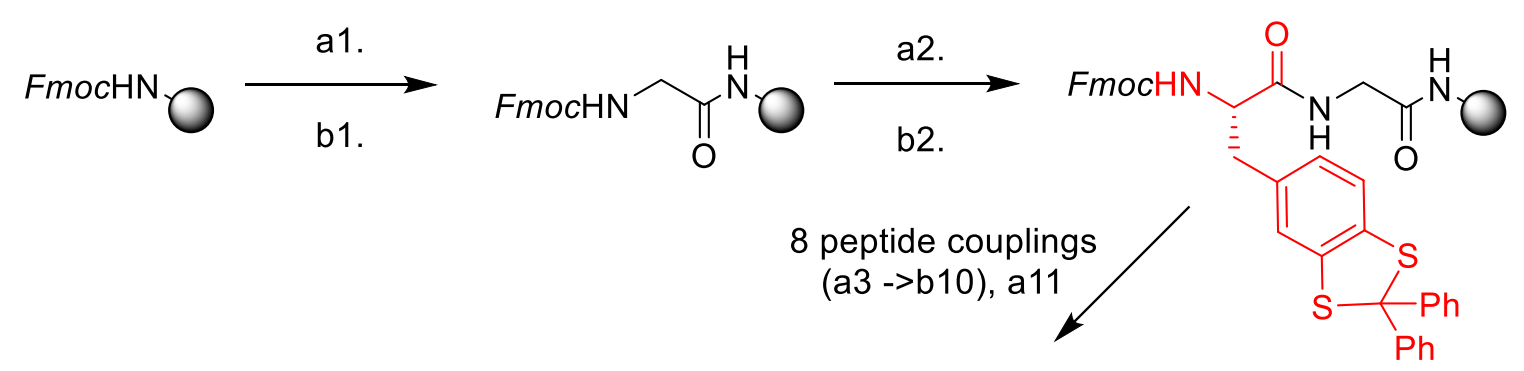

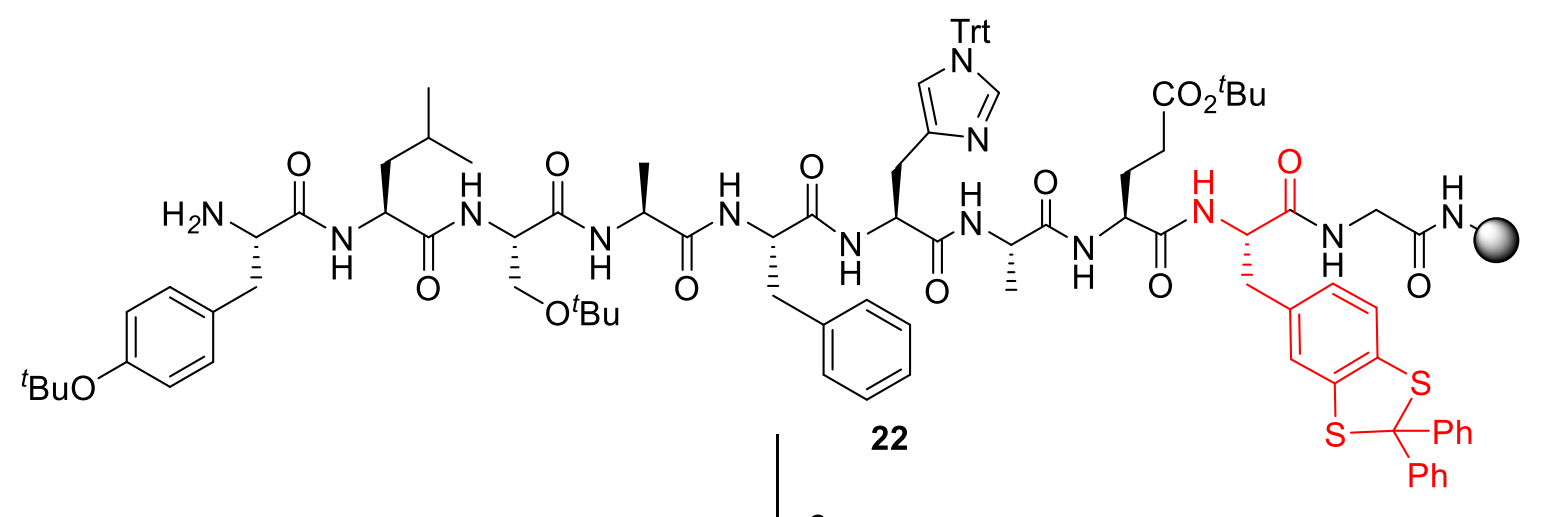

c.<smiles>CC(C)C[C@H](NC(=O)[C@H](N)Cc1ccc(O)cc1)C(=O)N[C@@H](CO)C(=O)N[C@@H](C)C(=O)N[C@@H](Cc1ccccc1)C(=O)N[C@@H](Cc1c[nH]cn1)C(=O)N[C@@H](C)C(=O)N[C@@H](CCC(=O)O)C(=O)N[C@@H](Cc1ccc2c(c1)SC(c1ccccc1)(c1ccccc1)S2)C(=O)NCC(N)=O</smiles>

d.

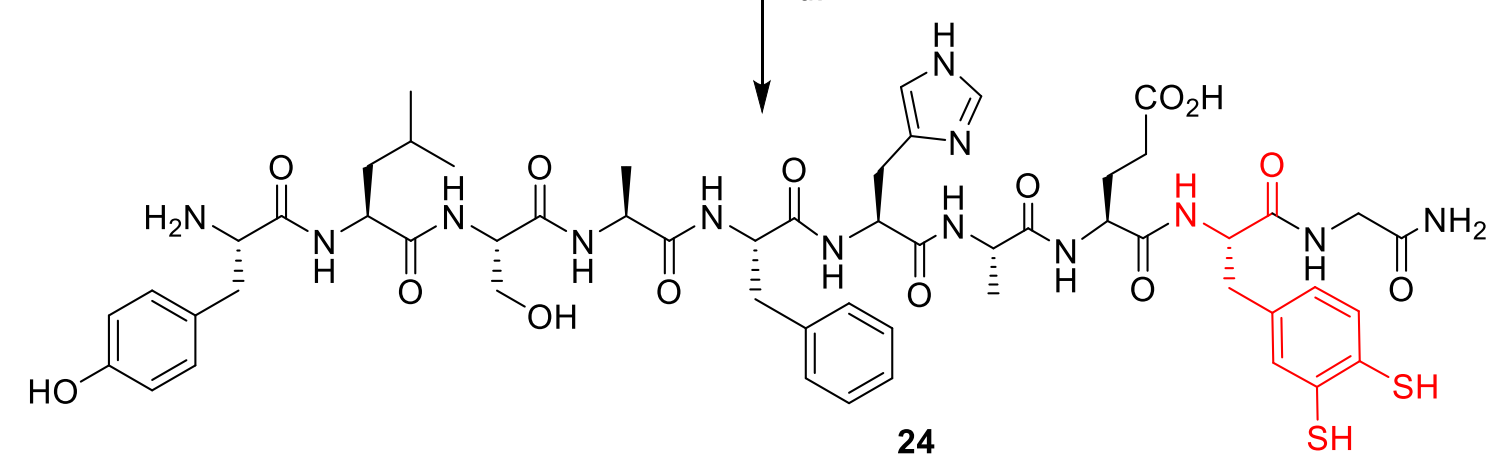

Scheme 6. Synthesis of a decapeptide containing the dithiol function. Reagents and conditions:

a) $20 \%$ piperidine in DMF (2 x $4.5 \mathrm{~mL}), 3$ and $10 \mathrm{~min}$; b) Fmoc-protected amino-acids (5 
equiv.) DIEA (10 equiv), $\mathrm{HBTU}$ (4.9 equiv), DMF, $75^{\circ} \mathrm{C}, 5 \mathrm{~min}$; exceptions: b2) first: 19a-S (2 equiv), HBTU (2 equiv), DIEA (4 equiv), DMF, RT, 60 min; second: 19a-S (1.1 equiv), HBTU (1.1 equiv), DIEA (2.2 equiv), DMF, RT, 1 h; b5) Fmoc-His(Trt)-OH (5 equiv.) DIEA (10 equiv), HBTU (4.9 equiv), DMF, 50 ${ }^{\circ} \mathrm{C}, 6.5 \mathrm{~min}$; c) TFA/TIS/water (95/2.5/2.5), RT, $2 \mathrm{~h}$; d) (i) $\mathrm{HgO}$ (1.5 equiv), $\mathrm{HBF}_{4} 35$ wt. \% in $\mathrm{H}_{2} \mathrm{O}$ (6.8 equiv), RT, THF, 2 h ; (ii) $\mathrm{H}_{2} \mathrm{~S}$ gas, EtOAc/MeOH (95:5), RT, 4 h.

\section{CONCLUSION}

We describe herein a convenient method for the preparation of racemic 3,4- and 2,3dimercaptophenylalanines, as new entries in the non-canonical amino acid library. The key synthetic step involves the deprotection of thioketal function to obtain the free dimercaptophenylalanines. A method for the chiral resolution using preparative chiral HPLC is also reported and the absolute configuration of the enantiomers could be assigned based on X-ray structure and Vibrational Circular Dichroism spectra correlated to DFT calculations. These building blocks are compatible with Fmoc peptide synthesis and a decapeptide including the L$\mathrm{F}^{3,4-\mathrm{dt}}$ residue was prepared, thus confirming the viability of our dithiolene protection scheme. Indeed, the thioketal deprotection was carried out successfully to obtain the dithiolene-containing decapeptide. After purification, XPS analysis indicated that the dithiolene-containing amino acids and decapeptide were free from $\mathrm{Hg}$ contamination. We are currently developing new peptide sequences whose applications will be exploiting the chemical and physical properties of the dithiolene side-chains.

\section{EXPERIMENTAL SECTION}




\section{General Methods}

All reagents were purchased from commercial sources and used without further purification, unless otherwise stated. Petroleum ether (Pet-ether) refers to the fraction of petroleum boiling between $60-80{ }^{\circ} \mathrm{C}$. The following abbreviations are used for $\mathrm{MeCN}=$ acetonitrile, $\mathrm{THF}=$ tetrahydrofuran, $\mathrm{DCM}=$ dichloromethane, EtOAc = ethyl acetate, $\mathrm{MeOH}=$ methanol, $\mathrm{Et}_{2} \mathrm{O}=$ diethylether, $\mathrm{p}$-TSA $=p$-Toluenesulfonic acid, TFA $=$ trifluoroacetic acid, TIS $=$ trisisopropylsilane. All reactions were carried out in oven-dried glassware under an argon atmosphere using anhydrous solvents, standard syringe and septum techniques unless otherwise indicated. Organic extracts were dried over anhydrous $\mathrm{Na}_{2} \mathrm{SO}_{4}$ and then filtered prior to removal of all volatiles under reduced pressure on rotary evaporation. Chromatographic purification of products was accomplished using column chromatography on silica gels (mesh $100 \sim 200$ ). Thinlayer chromatography (TLC) was carried out on aluminum sheets, Silica Gel 60 F254 (Merck; layer thickness $0.25 \mathrm{~mm}$ ). Visualization of the developed chromatogram was performed by UV light and /or phosphomolybdic acid stains. Optical rotations were measured on a Jasco P-2000 polarimeter with a sodium lamp (589 nm), a halogen lamp (880, 578, 546, 436, 405 and $325 \mathrm{~nm})$, in a $10 \mathrm{~cm}$ cell, thermostated at $25^{\circ} \mathrm{C}$ with a Peltier controlled cell holder. Electronic Circular Dichroism spectra was measured on a JASCO J-815 spectrometer equipped with a JASCO Peltier cell holder PTC-423 to maintain the temperature at $25.0 \pm 0.2^{\circ} \mathrm{C}$. A CD quartz cell of 1 mm of optical path length was used. IR spectra were recorded as thin films (for liquids). ${ }^{1} \mathrm{H}$ and ${ }^{13} \mathrm{C}$ NMR spectra were recorded at 300 or $500 \mathrm{MHz}$ and 75 or $125 \mathrm{MHz}$, respectively using $\mathrm{CDCl}_{3}$ and $\mathrm{CD}_{3} \mathrm{OD}$ as solvent. Chemical shifts $(\delta)$ are given in ppm relative to the solvent residual peak or TMS as internal standard. The following abbreviations are used for multiplicity of NMR signals: $\mathrm{s}=$ singlet, $\mathrm{d}=$ doublet, $\mathrm{t}=$ triplet, $\mathrm{m}=$ multiplet, $\mathrm{br}=$ broad. High Resolution 
Mass Spectra (HRMS) were measured in a QTOF I (quadrupole-hexapole-TOF) mass spectrometer with an orthogonal Z-spray-electrospray interface on Micro (YA-263) mass spectrometer (Manchester, UK) and Matrix-Assisted Laser Desorption Ionization (MALDI) mass spectra were recorded on Bruker ultrafleXtreme MALDI-TOF system. An automated peptide synthesiser Biotage Initiator + Alstra was used for the solid-phase peptide synthesis. All Fmocprotected amino acids were purchased as L-enantiomers from Novabiochem.

\section{Route a: $\quad N, N^{\prime}$-(4-methyl-1,2-phenylene)bis(sulfanediyl)bis-(methylene)diacetamide (3)} using HCl: To a mixture of N-(hydroxymethyl)acetamide (181 mg, $2 \mathrm{mmol})$ and $98.2 \mathrm{mg}(0.628$ mmol) of 2 , in $50 \mathrm{ml}$ of water, was cooled in an ice bath and $20 \mathrm{ml}$ of concentrated hydrochloric acid was added. The flask was stoppered and stirred for 1 day at room temperature under argon. After completion, the reaction mixture was concentrated in vacuo and the residue was evaporated with ethanol for four times. The crude product was purified by silica gel column chromatography using DCM/MeOH (95:5) to obtain the product 3 (84 mg, 45\%), $\left(\mathrm{R}_{\mathrm{f}}=0.6, \mathrm{DCM} / \mathrm{MeOH}, 95: 5\right)$. ${ }^{1} \mathrm{H} \mathrm{NMR}\left(400 \mathrm{MHz}, \mathrm{CDCl}_{3}\right): \delta=7.29(\mathrm{~d}, J=7.6 \mathrm{~Hz}, 1 \mathrm{H}), 7.22(\mathrm{~s}, 1 \mathrm{H}), 6.99(\mathrm{~d}, J=7.6 \mathrm{~Hz}, 1 \mathrm{H})$, 6.78 (brs, 1H), 6.66 (brs, 1H), 2.29 (s, 3H), 1.89 (s, 2H), 1.87 (s, 1H) ppm. ${ }^{13} \mathrm{C}\{1 \mathrm{H}\}$ NMR $(100$ $\left.\mathrm{MHz}, \mathrm{CDCl}_{3}\right) \delta=170.5,138.8,136.8,133.6,132.9,131.9,128.8,43.4,43.0,23.0,21.1 \mathrm{ppm} . \mathrm{IR}$ (Neat) $v_{\max }=3278,3064,29.28,1557,1542,1255 \mathrm{~cm}^{-1}$. HRMS (ESI): $m / z[\mathrm{M}+\mathrm{Na}]^{+}$calcd for $\mathrm{C}_{13} \mathrm{H}_{18} \mathrm{O}_{2} \mathrm{~N}_{2} \mathrm{~S}_{2} \mathrm{Na}: 321.0707$; found: 321.0706. MALDI-TOF: $\left(\mathrm{M}=\mathrm{C}_{13} \mathrm{H}_{19} \mathrm{~N}_{2} \mathrm{O}_{2} \mathrm{~S}_{2}\right) 284.56$ [M$\left.\mathrm{CH}_{3}+\mathrm{H}\right]^{+}$.

\section{Route b: $\quad N, N^{\prime}$-(4-methyl-1,2-phenylene)bis(sulfanediyl)bis-(methylene)diacetamide (3)} using TMS-Cl: To a solution of $N$-(hydroxymethyl)acetamide $(288 \mathrm{mg}, 3.23 \mathrm{mmol}$ ) in anhydrous THF ( $4 \mathrm{~mL})$ was added TMS-Cl $(256 \mu \mathrm{L}, 2.02 \mathrm{mmol})$. The solution was allowed to 
stir for $10 \mathrm{~min}$. In a separate flask, toluene-3,4-dithiol $(158.5 \mathrm{mg}, 1.01 \mathrm{mmol})$ was dissolved in anhydrous THF (4 mL), and this solution was transferred via cannula under argon to the stirring solution and allowed to stir for $12 \mathrm{~h}$. Upon completion of the reaction (monitored by TLC), the reaction mixture was quenched with water. The aqueous layer was then extracted with ethyl acetate 3 times and the organic layers were combined, dried over sodium sulfate. The crude product was purified by silica gel column chromatography using DCM/MeOH (95:5) to obtain the product 3 (145 $\mathrm{mg}, 48 \%)$.

5-Methyl-1,3-benzodithiol-2-one (4) ${ }^{29}$ : Compound 2 (7.55 mmol, $\left.1.18 \mathrm{~g}, 1 \mathrm{~mL}\right)$ was dissolved in $35 \mathrm{~mL}$ of tetrahydrofuran. To the stirring solution, carbonyldiimidazole $(7.48 \mathrm{mmol}, 1.21 \mathrm{~g})$ was added as a solid. The solution was stirred at room temperature under nitrogen and the reaction was monitored by thin-layer chromatography $\left(\mathrm{SiO}_{2} /\right.$ pentane: $\mathrm{Et}_{2} \mathrm{O}$ 50:1). After 14 hours, more carbonyldiimidazole $(1.36 \mathrm{mmol}, 220 \mathrm{mg})$ was added and the solution stirred for 4 additional hours. The solution was then dried in vacuo affording a white solid. $65 \mathrm{~mL}$ of $0.1 \mathrm{M}$ hydrochloric acid and $60 \mathrm{~mL}$ of chloroform were added to the solid and the suspension was transferred to a separatory funnel. Following phase separation, the organic phase was reextracted with $2 \times 65 \mathrm{~mL}$ of $0.1 \mathrm{M}$ hydrochloric acid and $2 \times 60 \mathrm{~mL}$ of water. The organic layer was then dried over $\mathrm{Na}_{2} \mathrm{SO}_{4}$, filtered and the solvent was removed in vacuo, affording the title compound as a white solid (1.265 g, $92 \%$ yield $),\left(\mathrm{R}_{\mathrm{f}}=0.7\right.$, Pet-ether/EtOAc, 95:5). ${ }^{1} \mathrm{H}$ NMR $\left(300 \mathrm{MHz}, \mathrm{CDCl}_{3}\right): \delta=7.35(\mathrm{~d}, J=8.1 \mathrm{~Hz}, 1 \mathrm{H}), 7.30(\mathrm{~s}, 1 \mathrm{H}), 7.13(\mathrm{~d}, J=8.1 \mathrm{~Hz}, 1 \mathrm{H}), 2.39(\mathrm{~s}$, 3H) ppm. ${ }^{13} \mathrm{C}\{1 \mathrm{H}\} \mathrm{NMR}\left(100 \mathrm{MHz}, \mathrm{CDCl}_{3}\right) \delta=190.5,137.4,132.7$ 129.4, 128.2, 123.5, 122.9, 21.4 ppm. IR (Neat) $v_{\max }=2926,1740,1693,1647,1452,887,843 \mathrm{~cm}^{-1}$. HRMS (ESI): $m / z[\mathrm{M}+$ $\mathrm{H}]^{+}$calcd for $\mathrm{C}_{8} \mathrm{H}_{7} \mathrm{OS}_{2}: 182.9933$; found: 182.9930 . 
5-Methyl-2,2-diphenylbenzo[d][1,3]dithiol (5): Compound 2 (300 $\mathrm{mg}, 1.92$ mmol), dimethoxydiphenylmethane ( $658 \mathrm{mg}, 2.88 \mathrm{mmol}), p$-TSA (36.5 mg, $0.192 \mathrm{mmol})$ were dissolved in dry toluene and the reaction mixture was refluxed for $12 \mathrm{~h}$ in Dean-Stark apparatus. Then toluene was removed by evaporation and crude mixture was dissolved in chloroform and washed with $1 \mathrm{~N} \mathrm{HCl}$, water and brine, dried over $\mathrm{Na}_{2} \mathrm{SO}_{4}$. The crude mixture was purified by flash column chromatography using $\mathrm{Et}_{2} \mathrm{O} /$ Pet-ether (1:99) to give 5 as white solid (603 $\mathrm{mg}, 98 \%$ yield), $\left(\mathrm{R}_{\mathrm{f}}=0.6\right.$, Pet-ether/EtOAc, 95:5). ${ }^{1} \mathrm{H} \mathrm{NMR}\left(300 \mathrm{MHz}, \mathrm{CDCl}_{3}\right): \delta=7.66(\mathrm{~d}, J=7.7 \mathrm{~Hz}$, 4H), 7.33-7.22 (m, 6H), $7.09(\mathrm{~d}, J=7.9 \mathrm{~Hz}, 1 \mathrm{H}), 7.04(\mathrm{~s}, 1 \mathrm{H}), 6.84(\mathrm{~d}, J=7.8 \mathrm{~Hz}, 1 \mathrm{H}), 2.25(\mathrm{~s}$, $3 \mathrm{H}) \mathrm{ppm} .{ }^{13} \mathrm{C}\{1 \mathrm{H}\} \mathrm{NMR}\left(75 \mathrm{MHz}, \mathrm{CDCl}_{3}\right): \delta=143.3,138.0,136.1,134.6,128.2,128.1,127.8$, 126.9, 123.0, 122.0, 78.1, $21.1 \mathrm{ppm}$. IR (Neat) $v_{\max }=3055,2918,1489,1457,1443 \mathrm{~cm}^{-1}$. HRMS (ESI): $m / z[\mathrm{M}]^{+}$calcd for $\mathrm{C}_{20} \mathrm{H}_{16} \mathrm{~S}_{2}: 320.0693$; found: 320.0695 .

\section{Literature Preparations:}

Compounds 9a $1,9 \mathbf{b}_{1}, 9 \mathbf{a}_{2}, 9 \mathbf{b}_{2}, 10 a, 10 \mathbf{b}$ were prepared according to reported literature procedures. ${ }^{15}$ Spectroscopic data of all the compounds are in good agreement with those previously reported.

3,4-Dimercaptobenzoic acid (8a) ${ }^{15}$ : An aqueous solution of $\mathrm{NaOH}(1 \mathrm{~N}, 10 \mathrm{~mL})$ was added to compound 10a (392 mg, $1.734 \mathrm{mmol})$. The resulting mixture was heated at $70{ }^{\circ} \mathrm{C}$ using silicone oil bath under argon atmosphere for $6 \mathrm{~h}$. The reaction mixture was cooled to RT and acidified with $1 \mathrm{~N} \mathrm{HCl}$. The white precipitate was dissolved in EtOAc, washed several times with water, and dried over $\mathrm{Na}_{2} \mathrm{SO}_{4}$ and concentrated to afford the product 8a, as a yellow solid (361 $\mathrm{mg}$, 92\%). ${ }^{1} \mathrm{H}$ NMR $\left(300 \mathrm{MHz}, \mathrm{CD}_{3} \mathrm{OD}\right) \delta=7.97(\mathrm{~s}, 1 \mathrm{H}), 7.62(\mathrm{~d}, J=8.1 \mathrm{~Hz}, 1 \mathrm{H}), 7.41(\mathrm{~d}, J=8.1$ 
$\mathrm{Hz}, 1 \mathrm{H}) \mathrm{ppm} .{ }^{13} \mathrm{C}\{1 \mathrm{H}\} \mathrm{NMR}\left(75 \mathrm{MHz}, \mathrm{CD}_{3} \mathrm{OD}\right) \delta=168.9,140.4,132.9,131.4,130.4,129.4$, $128.4 \mathrm{ppm} . \mathrm{IR}$ (Neat) $v_{\max }=2924,2854,1681,1586,1314,762 \mathrm{~cm}^{-1}$.

2,3-Dimercaptobenzoic acid (8b) ${ }^{15 a}$ : Starting from the compound 10b (400 mg, $\left.1.169 \mathrm{mmol}\right)$, $\mathbf{8 b}$ was synthesized following the procedure of $\mathbf{8 a}$. The product $\mathbf{8 b}$ was obtained as a yellow solid (202 mg, 93\%). ${ }^{1} \mathrm{H}$ NMR (300 MHz, $\left.\mathrm{CD}_{3} \mathrm{OD}\right) \delta=7.86(\mathrm{~d}, J=7.8 \mathrm{~Hz}, 1 \mathrm{H}), 7.54(\mathrm{~d}, J=7.5$ $\mathrm{Hz}, 1 \mathrm{H}), 7.02(\mathrm{t}, J=7.8 \mathrm{~Hz}, 1 \mathrm{H}) \mathrm{ppm} .{ }^{13} \mathrm{C}\{1 \mathrm{H}\} \mathrm{NMR}\left(75 \mathrm{MHz}, \mathrm{CD}_{3} \mathrm{OD}\right) \delta=170.7,138.5$, $135.4,133.5,130.6,128.7,124.9$. IR (Neat) $v_{\max }=2497,1664,1395,1314,1268,744 \mathrm{~cm}^{-1}$.

2,2-Diphenylbenzo[d][1,3]dithiole-5-carboxylic acid (11a): Compound 8a together with dimethoxydiphenylmethane (474 mg, $2.081 \mathrm{mmol})$, pTSA (30 mg, $0.173 \mathrm{mmol})$ were dissolved in $5 \mathrm{~mL}$ dry toluene and the reaction mixture was refluxed in silicone oil bath for $12 \mathrm{~h}$ using Dean-Stark apparatus. Toluene was then removed by evaporation and crude mixture was dissolved in chloroform and washed with $1 \mathrm{~N} \mathrm{HCl}$, water and brine, dried over $\mathrm{Na}_{2} \mathrm{SO}_{4}$. The crude product was purified by flash column chromatography using $\mathrm{DCM} / \mathrm{MeOH}(98: 2)$ to give 11a as a white solid (509 mg, 84\% yield), $\left(\mathrm{R}_{\mathrm{f}}=0.45\right.$, DCM/MeOH, 95:5). ${ }^{1} \mathrm{H}$ NMR (300 MHz, $\left.\mathrm{CDCl}_{3}\right): \delta=7.85(\mathrm{~s}, 1 \mathrm{H}), 7.69(\mathrm{dd}, J=8.1,1.5 \mathrm{~Hz}, 1 \mathrm{H}), 7.62-7.59(\mathrm{~m}, 4 \mathrm{H}), 7.34-7.22(\mathrm{~m}, 7 \mathrm{H})$ ppm. ${ }^{13} \mathrm{C}\{1 \mathrm{H}\}$ NMR $\left(75 \mathrm{MHz}, \mathrm{CDCl}_{3}\right): \delta=167.9,143.8,142.6,138.3,128.4,128.1,128.0$, 127.9, 127.7, 123.1, 121.6, 78.3 ppm. IR (Neat) $v_{\max }=3059,2928,1719,1689,1657,1276 \mathrm{~cm}^{-1}$. HRMS (ESI): $\mathrm{m} / z[\mathrm{M}+\mathrm{H}]^{+}$calcd for $\mathrm{C}_{20} \mathrm{H}_{15} \mathrm{O}_{2} \mathrm{~S}_{2}: 351.0508$; found: 351.0506 .

2,2-Diphenylbenzo[d][1,3]dithiole-4-carboxylic acid (11b): Starting from the compound $8 \mathrm{~b}$ (500 $\mathrm{mg}, 2.684 \mathrm{mmol}$ ), 11b was synthesized following the procedure of 11a. The white solid product $11 \mathrm{~b}$ was obtained in $81 \%(761 \mathrm{mg})$ yield, $\left(\mathrm{R}_{\mathrm{f}}=0.5, \mathrm{DCM} / \mathrm{MeOH}, 95: 5\right) ;{ }^{1} \mathrm{H}$ NMR $(300$ $\left.\mathrm{MHz}, \mathrm{CDCl}_{3}\right): \delta=7.75(\mathrm{~d}, J=7.8 \mathrm{~Hz}, 1 \mathrm{H}), 7.60(\mathrm{~d}, J=7.5 \mathrm{~Hz}, 4 \mathrm{H}), 7.32(\mathrm{~d}, J=7.6 \mathrm{~Hz}, 1 \mathrm{H})$, 
$7.28-7.20(\mathrm{~m}, 6 \mathrm{H}), 7.05(\mathrm{t}, J=7.70 \mathrm{~Hz}, 1 \mathrm{H}) \mathrm{ppm} .{ }^{13} \mathrm{C}\{1 \mathrm{H}\} \mathrm{NMR}\left(75 \mathrm{MHz}, \mathrm{CDCl}_{3}\right): \delta=168.2$ $143.5,141.9,139.5,128.2,128.1,127.6,125.6,125.3,124.9,75.5$ ppm. IR (Neat) $v_{\max }=3061$, 2662, 1678, 1433, 1278, $750 \mathrm{~cm}^{-1}$. HRMS (ESI): $\mathrm{m} / z[\mathrm{M}+\mathrm{Na}]^{+}$calcd for $\mathrm{C}_{20} \mathrm{H}_{14} \mathrm{O}_{2} \mathrm{~S}_{2} \mathrm{Na}$ : 373.0333; found: 373.0331 .

Methyl 2,2-diphenylbenzo[d][1,3]dithiole-5-carboxylate (12a): To a stirred solution of compound 11a (265 mg, $0.756 \mathrm{mmol})$ in anhydrous DMF (3.5 ml), $\mathrm{K}_{2} \mathrm{CO}_{3}(209 \mathrm{mg}, 1.51 \mathrm{mmol})$ was added portion wise at $0{ }^{\circ} \mathrm{C}$. The mixture was stirred at RT for $10 \mathrm{~min}$ and again cooled to 0 ${ }^{\circ} \mathrm{C}$, treated with $\mathrm{CH}_{3} \mathrm{I}(0.188 \mathrm{ml}, 3.024 \mathrm{mmol})$ and allowed to stir at RT for $12 \mathrm{~h}$. After completion of reaction, the reaction mixture was quenched with $\mathrm{NH}_{4} \mathrm{Cl}(5 \mathrm{ml})$, extracted with EtOAc $(3 \times 5 \mathrm{ml})$. The organic layers were combined, washed with brine, dried over $\mathrm{Na}_{2} \mathrm{SO}_{4}$ and concentrated in vacuo. The crude product was purified by column chromatography using Petether/EtOAc (95:5) on silica gel to afford a white solid 12a $\left(226 \mathrm{mg}, 84 \%\right.$ yield), $\left(\mathrm{R}_{\mathrm{f}}=0.5\right.$, Petether/EtOAc, 90:10). ${ }^{1} \mathrm{H}$ NMR (300 MHz, $\left.\mathrm{CDCl}_{3}\right): \delta=7.53(\mathrm{~d}, J=1.6 \mathrm{~Hz}, 1 \mathrm{H}), 7.35(\mathrm{dd}, J=$ 8.2, $1.6 \mathrm{~Hz}, 1 \mathrm{H}), 7.30-7.26(\mathrm{~m}, 4 \mathrm{H}), 6.99-6.89(\mathrm{~m}, 7 \mathrm{H}), 3.52(\mathrm{~s}, 3 \mathrm{H}) \mathrm{ppm} .{ }^{13} \mathrm{C}\{1 \mathrm{H}\} \mathrm{NMR}(75$ $\left.\mathrm{MHz}, \mathrm{CDCl}_{3}\right): \delta=166.3,144.0,142.7,138.6,128.3,128.2,128.1,127.6,123.0,121.8,78.5$ $52.2 \mathrm{ppm}$. IR (Neat) $v_{\max }=2950,1717,1582,1430,1285,1234 \mathrm{~cm}^{-1}$. HRMS (ESI): $\mathrm{m} / z[\mathrm{M}+$ $\mathrm{H}]^{+}$calcd for $\mathrm{C}_{21} \mathrm{H}_{17} \mathrm{O}_{2} \mathrm{~S}_{2}: 365.0670$; found: 365.0665 .

Methyl 2,2-diphenylbenzo[d][1,3]dithiole-4-carboxylate (12b): 12b was synthesized from compound 11b (150 mg, $0.428 \mathrm{mmol}$ ) following the procedure of 12a. Isolated yield of white solid product $12 \mathbf{b}$ was $81 \%(126 \mathrm{mg}),\left(\mathrm{R}_{\mathrm{f}}=0.5\right.$, Pet-ether/EtOAc, 90:10); ${ }^{1} \mathrm{H}$ NMR $(300 \mathrm{MHz}$, $\left.\mathrm{CDCl}_{3}\right): \delta=7.33(\mathrm{dd}, J=7.9,1.1 \mathrm{~Hz}, 1 \mathrm{H}), 7.27-7.23(\mathrm{~m}, 4 \mathrm{H}), 6.95-6.81(\mathrm{~m}, 7 \mathrm{H}), 6.65(\mathrm{t}, J=$ $7.8 \mathrm{~Hz}, 1 \mathrm{H}), 3.50(\mathrm{~s}, 3 \mathrm{H}) \mathrm{ppm} .{ }^{13} \mathrm{C}\{1 \mathrm{H}\} \mathrm{NMR}\left(75 \mathrm{MHz}, \mathrm{CDCl}_{3}\right): \delta=166.4,143.5,141.8,139.7$, 
$128.2,128.1,127.7,127.6,125.5,125.4,124.5,75.6,52.5 \mathrm{ppm} . \mathrm{IR}$ (Neat) $v_{\max }=3058,2949$, 1705, 1443, 1403, 1301, 1270, $746 \mathrm{~cm}^{-1}$. HRMS (ESI): $\mathrm{m} / z[\mathrm{M}+\mathrm{Na}]^{+}$calcd for $\mathrm{C}_{21} \mathrm{H}_{16} \mathrm{O}_{2} \mathrm{~S}_{2} \mathrm{Na}$ : 387.0490; found: 387.0492 .

(2,2-Diphenylbenzo[d][1,3]dithiol-5-yl)methanol (13a): Anhydrous $\mathrm{AlCl}_{3}(285.19 \mathrm{mg}, 2.14$ mmol) was added portion wise to a suspension of $\mathrm{LiAlH}_{4}(270.58 \mathrm{mg}, 7.13 \mathrm{mmol})$ in $5 \mathrm{ml}$ of anhydrous $\mathrm{Et}_{2} \mathrm{O}$ under argon atmosphere at $0{ }^{\circ} \mathrm{C}$. The reaction mixture was stirred at the same temperature for $5 \mathrm{~min}$, the ester compound 12a $(260 \mathrm{mg}, 0.71 \mathrm{mmol})$ dissolved in $8 \mathrm{ml}$ of anhydrous $\mathrm{Et}_{2} \mathrm{O}$ was cannula transferred to the stirring solution over a period of $10 \mathrm{~min}$. The resulting mixture was continuously stirred at $0{ }^{\circ} \mathrm{C}$ for $5 \mathrm{~min}$ and then quenched with $0.1 \mathrm{~N} \mathrm{HCl}$ and extracted with $\mathrm{Et}_{2} \mathrm{O}(3 \times 5 \mathrm{ml})$. The combined organic extracts were washed with water and brine, dried over $\mathrm{Na}_{2} \mathrm{SO}_{4}$ and concentrated in vacuo. The residue was purified by column chromatography using Pet-ether/EtOAc (4:1) on silica gel to afford the alcohol 13a as a colorless oil (220 mg, 92\% yield), $\left(\mathrm{R}_{\mathrm{f}}=0.5\right.$, Pet-ether/EtOAc, 85:15). ${ }^{1} \mathrm{H}$ NMR (300 MHz, $\left.\mathrm{CDCl}_{3}\right): \delta=$ 7.65-7.57 (m, 4H), 7.34-7.20 (m, 6H), 7.16-7.12 (m, 1H), 7.04 (d, $J=7.8 \mathrm{~Hz}, 0.5 \mathrm{H}), 6.95$ (d, $J$ $=10.2 \mathrm{~Hz}, 1 \mathrm{H}), 6.82(\mathrm{~d}, J=7.88 \mathrm{~Hz}, 0.5 \mathrm{H}), 4.51(\mathrm{~d}, J=12.7 \mathrm{~Hz}, 2 \mathrm{H}), 1.89(\mathrm{~s}, 1 \mathrm{H}) \mathrm{ppm}$. ${ }^{13} \mathrm{C}\{1 \mathrm{H}\}$ NMR $\left(75 \mathrm{MHz}, \mathrm{CDCl}_{3}\right) \delta=155.0,143.1,142.9,139.6,139.1,138.4,137.2,128.5$, $128.2,127.9,126.9,124.9,122.2,121.6,121.4,120.9,109.7,78.2,65.0,64.7$ ppm. IR (Neat) $v_{\max }=3404,2950,1431,1289,1240 \mathrm{~cm}^{-1} . \mathrm{HRMS}(\mathrm{ESI}): \mathrm{m} / z[\mathrm{M}+\mathrm{Na}]^{+}$calcd for $\mathrm{C}_{20} \mathrm{H}_{16} \mathrm{OS}_{2} \mathrm{Na}:$ 359.0540; found: 359.0542 .

(2,2-Diphenylbenzo[d][1,3]dithiol-4-yl)methanol (13b): Starting from compound 12b (254 $\mathrm{mg}, 0.697 \mathrm{mmol}$ ), 13b was synthesized following the procedure of 13a. Isolated yield of the oily colorless product $\mathbf{1 3 b}$ was $91 \%(213 \mathrm{mg}),\left(\mathrm{R}_{\mathrm{f}}=0.5\right.$, Pet-ether/EtOAc, 85:15); ${ }^{1} \mathrm{H}$ NMR (400 
$\left.\mathrm{MHz}, \mathrm{CDCl}_{3}\right): \delta=7.70(\mathrm{~d}, J=7.0 \mathrm{~Hz}, 4 \mathrm{H}), 7.35-7.28(\mathrm{~m}, 6 \mathrm{H}), 7.19(\mathrm{dd}, J=7.4,1.1 \mathrm{~Hz}, 1 \mathrm{H})$, 7.10-7.03 (m, 2H), $4.59(\mathrm{~s}, 3 \mathrm{H}), 2.15(\mathrm{~s}, 1 \mathrm{H}) \mathrm{ppm} .{ }^{13} \mathrm{C}\{1 \mathrm{H}\} \mathrm{NMR}\left(100 \mathrm{MHz}, \mathrm{CDCl}_{3}\right): \delta=143.1$, $138.6,136.4,135.2,128.1,127.9,126.1,124.9,121.5,77.8,64.7 \mathrm{ppm}$. IR (Neat) $v_{\max }=3363$, 3058, 2870, 1489, 1443, 1249, 753, $695 \mathrm{~cm}^{-1}$. HRMS (ESI): $\mathrm{m} / \mathrm{z}[\mathrm{M}+\mathrm{Na}]^{+}$calcd for $\mathrm{C}_{20} \mathrm{H}_{16} \mathrm{OS}_{2} \mathrm{Na}$ : 359.0540; found: 359.0541 .

\section{5-(Bromomethyl)-2, 2-diphenylbenzo[d][1,3]dithiol (7a):}

Route A: To an ice-cold solution of $\mathrm{PBr}_{3}(0.055 \mathrm{ml}, 0.588 \mathrm{mmol})$ in $4 \mathrm{ml}$ of anhydrous $\mathrm{Et}_{2} \mathrm{O}$ under argon was added dropwise a solution of compound 13a $(153 \mathrm{mg}, 0.59 \mathrm{mmol})$ in $6 \mathrm{ml}$ anhydrous $\mathrm{Et}_{2} \mathrm{O}$ and the mixture was allowed to stir at $0{ }^{\circ} \mathrm{C}$ for $4 \mathrm{~h}$. After completion of the reaction (TLC monitoring), the solvent was evaporated and the reaction mixture was diluted with EtOAc $(15 \mathrm{ml})$. The combined organic layers were washed with water, followed by brine. Drying over $\mathrm{Na}_{2} \mathrm{SO}_{4}$ and evaporation of the solvent under reduced pressure afforded the product as a white solid (160 mg, 85\% yield) which was used directly in the next reaction without further purification.

Route B: To a stirred solution of compound 5 (1.00 g, $3.12 \mathrm{mmol})$ in anhydrous $\mathrm{CH}_{2} \mathrm{Cl}_{2}(20$ $\mathrm{mL}$ ), was added $N$-bromosuccinimide $(555 \mathrm{mg}, 3.11 \mathrm{mmol})$. The solution was irradiated and heated to reflux with a halogen lamp $(500 \mathrm{~W})$ in silicone oil bath for $30 \mathrm{~min}$. At this point, more $\mathrm{N}$-bromosuccinimide (111 mg, $0.62 \mathrm{mmol}$ ) was added and the solution was irradiated and heated to reflux with the halogen lamp $(500 \mathrm{~W})$ for an additional hour. The reaction mixture was added to a separatory funnel and extracted with $4 \times 150 \mathrm{~mL}$ of a $0.1 \mathrm{M} \mathrm{NaHCO}_{3}$ solution, and then with $1 \times 150 \mathrm{~mL}$ water. Drying over $\mathrm{Na}_{2} \mathrm{SO}_{4}$ and evaporation of the solvent under reduced pressure afforded the product as an off-white powder. The crude product was recrystallized 2-fold from 
pentane to afford $7 \mathbf{a}$ as a white crystalline solid $(814 \mathrm{mg}, 65 \%$ yield $),\left(R_{\mathrm{f}}=0.7\right.$, Pet-ether/EtOAc, 95:5). ${ }^{1} \mathrm{H}$ NMR $\left(300 \mathrm{MHz}, \mathrm{CDCl}_{3}\right): \delta=7.58-7.54(\mathrm{~m}, 4 \mathrm{H}), 7.26-7.18(\mathrm{~m}, 6 \mathrm{H}), 7.15(\mathrm{~d}, J=$ $1.8 \mathrm{~Hz}, 1 \mathrm{H}), 7.08(\mathrm{~d}, J=8.1 \mathrm{~Hz}, 1 \mathrm{H}), 6.97(\mathrm{dd}, J=8.1,1.8 \mathrm{~Hz}, 1 \mathrm{H}), 4.31(\mathrm{~s}, 2 \mathrm{H}) \mathrm{ppm} .{ }^{13} \mathrm{C}\{1 \mathrm{H}\}$ NMR $\left(75 \mathrm{MHz}, \mathrm{CDCl}_{3}\right): \delta=143.0,138.8,138.5,135.9,128.3,128.0,127.0,122.8,122.3,78.4$, $33.1 \mathrm{ppm}$. IR (Neat) $v_{\max }=2960,2922,1633,1423,889,690 \mathrm{~cm}^{-1}$. HRMS (ESI) $:^{30} \mathrm{~m} / z[\mathrm{M}+$ $\mathrm{Na}]^{+}$calcd for $\mathrm{C}_{20} \mathrm{H}_{15} \mathrm{BrS}_{2} \mathrm{Na}$ : 420.9696; found: 420.9699 . The structure was deposited on the CCDC (CCDC 2035076)

4-(Bromomethyl)-2,2-diphenylbenzo[d][1,3]dithiol (7b): Starting from 13b (200 mg, 0.594 mmol), $7 \mathbf{b}$ was synthesized following the procedure of $7 \mathbf{a}$ via the route $\mathbf{A}$. The product $\mathbf{7 b}$ was obtained as a white crystalline solid in $85 \%(202 \mathrm{mg})$ yield, $\left(\mathrm{R}_{\mathrm{f}}=0.6\right.$, Pet-ether/EtOAc, $\left.95: 5\right) .{ }^{1} \mathrm{H}$ NMR (300 MHz, $\left.\mathrm{CDCl}_{3}\right): \delta=7.68-7.57(\mathrm{~m}, 4 \mathrm{H}), 7.35-7.21(\mathrm{~m}, 6 \mathrm{H}), 7.12(\mathrm{dd}, J=6.9,2.1 \mathrm{~Hz}$ 1H), $7.01-6.93(\mathrm{~m}, 2 \mathrm{H}), 6.87(\mathrm{~m}, 1 \mathrm{H}), 4.42(\mathrm{~s}, 1.25 \mathrm{H}), 4.35(\mathrm{~s}, 0.75 \mathrm{H}) \mathrm{ppm} .{ }^{13} \mathrm{C}\{1 \mathrm{H}\} \mathrm{NMR}(75$ $\left.\mathrm{MHz}, \mathrm{CDCl}_{3}\right): \delta=155.4,142.8,142.7,139.5,138.6,132.0,131.2,128.6,128.3,128.0,127.3$, 127.2, 127.0, 126.5, 126.4, 123.5, 122.5, 110.9, 78.2, 33.2, 32.6 ppm. IR (Neat) $v_{\max }=3058$, $1489,1442,1412,753,695 \mathrm{~cm}^{-1}$. HRMS (ESI): $\mathrm{m} / z\left([\mathrm{M}-\mathrm{Br}+\mathrm{Na}]^{+} 100 \%\right)$ calcd for $\mathrm{C}_{20} \mathrm{H}_{15} \mathrm{~S}_{2} \mathrm{Na}$ : 342.0513; found: 342.0515. The structure was deposited on the CCDC (CCDC 1840432).

\section{Diethyl 2-((2,2-diphenylbenzo[d][1,3]dithiol-5-yl)methyl)-2-(2,2,2-trifluoroacetamido)} malonate (6a): To a stirred solution of trifluoroacetamido malonate 16 (152 mg, $0.56 \mathrm{~mol})$ in 2.5 $\mathrm{ml}$ of anhydrous DMF was added $\mathrm{NaH}$ in $60 \%$ mineral oil $(26 \mathrm{mg}, 0.67 \mathrm{mmol})$ portion wise at 0 ${ }^{\circ} \mathrm{C}$. After being stirred at RT for $20 \mathrm{~min}$, the resulting mixture was further cooled to $0{ }^{\circ} \mathrm{C}$. The solution of bromide 7a (224 mg, $0.56 \mathrm{mmol})$ in $2 \mathrm{ml}$ anhydrous DMF was then transferred to the solution via cannula under argon at the same temperature. After the addition was completed, the 
reaction mixture was slowly warmed to RT and stirring was continued at the same temperature for $6 \mathrm{~h}$. After cooled to $0{ }^{\circ} \mathrm{C}$, the reaction mixture was diluted with EtOAc $(3 \times 5 \mathrm{ml})$, washed successively with $0.1 \mathrm{~N} \mathrm{HCl}$, water and brine, dried over $\mathrm{Na}_{2} \mathrm{SO}_{4}$ and concentrated. The residue was purified by column chromatography using ethyl acetate-petroleum ether (1: 9) on silica gel to afford 6a as a light yellowish gummy product (270 mg, $82 \%$ yield), $\left(\mathrm{R}_{\mathrm{f}}=0.5\right.$, Petether/EtOAc, 80:20). ${ }^{1} \mathrm{H}$ NMR (400 $\left.\mathrm{MHz}, \mathrm{CDCl}_{3}\right): \delta=7.62-7.55(\mathrm{~m}, 4 \mathrm{H}), 7.41$ (s, 1H), 7.35-7.22 (m, 6H), $7.04(\mathrm{dd}, J=39.6,7.9 \mathrm{~Hz}, 1 \mathrm{H}), 6.84(\mathrm{~d}, J=1.2 \mathrm{~Hz}, 1 \mathrm{H}), 6.62(\mathrm{~m}, 1 \mathrm{H}), 6.50$ $(\mathrm{dd}, J=7.8,1.3 \mathrm{~Hz}, 1 \mathrm{H}), 4.35-4.19(\mathrm{~m}, 4 \mathrm{H}), 3.59(\mathrm{~d}, J=11.9 \mathrm{~Hz}, 2 \mathrm{H}), 1.27(\mathrm{q}, J=7.1 \mathrm{~Hz}, 6 \mathrm{H})$ ppm. ${ }^{13} \mathrm{C}\{1 \mathrm{H}\} \operatorname{NMR}\left(100 \mathrm{MHz}, \mathrm{CDCl}_{3}\right): \delta=166.1,156.1(\mathrm{q}, 1 \mathrm{C}, J=38 \mathrm{~Hz}), 155.0,143.0$, $142.8,138.7,137.6,132.2,132.0,128.6,128.1,128.0,127.2,126.9,125.9,123.9,123.3,122.4$, $121.7,119.7,116.8,113.9,112.2,111.1,104.1,78.4,67.4,67.3,63.5,63.5,37.1,36.9,14.0$ ppm. IR (Neat) $v_{\max }=3392,2918,1729,1524,1443,1278,1168,1002,753,701 \mathrm{~cm}^{-1} . \mathrm{HRMS}$ (ESI): $m / z,[\mathrm{M}+\mathrm{K}]^{+}$calcd for $\mathrm{C}_{29} \mathrm{H}_{26} \mathrm{~F}_{3} \mathrm{NO}_{5} \mathrm{~S}_{2} \mathrm{~K}$ : 628.0842; found: 628.0844 .

\section{Diethyl 2-((2,2-diphenylbenzo[d][1,3]dithiol-4-yl)methyl)-2-(2,2,2-trifluoroacetamido)}

malonate (6b): $6 \mathbf{b}$ was synthesized from compound $\mathbf{7 b}(189 \mathrm{mg}, 0.473 \mathrm{mmol})$, following the same procedure of 6a. 6b was obtained as a light yellowish gummy product. Yield 75\% (209 $\mathrm{mg}),\left(\mathrm{R}_{\mathrm{f}}=0.5\right.$, Pet-ether/EtOAc, 80:20). ${ }^{1} \mathrm{H}$ NMR (400 MHz, $\left.\mathrm{CDCl}_{3}\right): \delta=7.55-7.53(\mathrm{~m}, 5 \mathrm{H})$, 7.37-7.27 (m, 6H), $7.15(\mathrm{~d}, J=8 \mathrm{~Hz}, 1 \mathrm{H}), 7.0-6.9(\mathrm{~m}, 1 \mathrm{H}), 6.7(\mathrm{~d}, J=7.6 \mathrm{~Hz}, 1 \mathrm{H}), 4.37-4.29$ $(\mathrm{m}, 2 \mathrm{H}), 4.25-4.16(\mathrm{~m}, 2 \mathrm{H}), 3.73(\mathrm{~s}, 2 \mathrm{H}), 1.28(\mathrm{t}, J=7.2 \mathrm{~Hz}, 6 \mathrm{H}) \mathrm{ppm} .{ }^{13} \mathrm{C}\{1 \mathrm{H}\} \mathrm{NMR}(100$ $\left.\mathrm{MHz}_{\mathrm{CDCl}}\right): \delta=166.14,166.11,156.4(\mathrm{q}, 1 \mathrm{C}, J=38 \mathrm{~Hz}), 155.1,143.0,142.9,139.6,138.9$, $128.7,128.6,128.2,128.16,128.03,127.97,126.9,126.3,126.0,124.3,121.6,116.8,114.0$, $110.2,103.5,66.9,63.59,63.55,38.4,37.5,13.9$ ppm. $v_{\max }=3386,3055,2984,1729,1519$, 
1444, 1216, 1167, $696 \mathrm{~cm}^{-1}$. HRMS (ESI): $\mathrm{m} / z[\mathrm{M}+\mathrm{H}]^{+}$calcd for $\mathrm{C}_{29} \mathrm{H}_{27} \mathrm{~F}_{3} \mathrm{NO}_{5} \mathrm{~S}_{2}: 590.1277$; found: 590.1276 .

Diethyl 2-acetamido-2-((2-phenylbenzo[d][1,3]dithiol-5-yl)methyl)malonate (17a): 17a was synthesized from $\mathbf{7 a}(170 \mathrm{mg}, 0.425 \mathrm{mmol})$ and malonate derivative 14, following the same procedure of 6a. 17a was obtained as a white solid product. Yield $65 \%(148 \mathrm{mg}),\left(\mathrm{R}_{\mathrm{f}}=0.5\right.$, Petether/EtOAc, 80:20). ${ }^{1} \mathrm{H}$ NMR (300 $\left.\mathrm{MHz}, \mathrm{CDCl}_{3}\right): \delta=7.53(\mathrm{dd}, J=8.4,1.8 \mathrm{~Hz}, 4 \mathrm{H})$, 7.24-7.14(m, 6H), $7.0(\mathrm{~d}, J=5.4 \mathrm{~Hz}, 1 \mathrm{H}), 6,78(\mathrm{~s}, 1 \mathrm{H}), 6.58(\mathrm{dd}, J=7.8,1.2 \mathrm{~Hz}, 1 \mathrm{H}), 6.47(\mathrm{~s}$, 1H), 4.23-4.10 (m, 4H), $3.47(\mathrm{~s}, 2 \mathrm{H}), 1.91(\mathrm{~s}, 3 \mathrm{H}), 1.17(\mathrm{t}, J=7.2 \mathrm{~Hz}, 6 \mathrm{H}) \mathrm{ppm} .{ }^{13} \mathrm{C}\{1 \mathrm{H}\} \mathrm{NMR}$ $\left(75 \mathrm{MHz}, \mathrm{CDCl}_{3}\right): \delta=169.2,167.4,143.1,138.2,136.9,133.5,128.2,128.0,127.6,123.6$, 122.1, 78.3, 67.2, 62.8, 37.5, 23.1, $14.1 \mathrm{ppm}$. IR (Neat) $v_{\max }=3405,3064,2983,1740,1680$, 1493, 1443, 1276, 1198, $696 \mathrm{~cm}^{-1}$. HRMS (ESI): $\mathrm{m} / z[\mathrm{M}+\mathrm{Na}]^{+}$calcd for $\mathrm{C}_{29} \mathrm{H}_{29} \mathrm{NO}_{5} \mathrm{~S}_{2} \mathrm{Na}$ : 558.1385; found: 558.1387 .

\section{Diethyl}

\section{2-(tert-butoxycarbonylamino)-2-((2,2-diphenylbenzo[d][1,3]dithiol-5-}

yl)methyl)malonate (18a): 18a was synthesized from 7a (165 mg, $0.413 \mathrm{mmol})$ and malonate derivative 15, following the same procedure of $\mathbf{6 a}$. Colorless oily product was obtained. Yield $32 \%(82 \mathrm{mg}),\left(\mathrm{R}_{\mathrm{f}}=0.5\right.$, Pet-ether/EtOAc, 80:20). ${ }^{1} \mathrm{H} \mathrm{NMR}\left(300 \mathrm{MHz}, \mathrm{CDCl}_{3}\right): \delta=7.62(\mathrm{dd}, J=$ 7.8, $1.5 \mathrm{~Hz}, 4 \mathrm{H}), 7.32-7.24(\mathrm{~m}, 6 \mathrm{H}), 7.07(\mathrm{~d}, J=8.1 \mathrm{~Hz}, 1 \mathrm{H}), 6.90(\mathrm{~s}, 1 \mathrm{H}), 6.70(\mathrm{~d}, J=7.8 \mathrm{~Hz}$ 1H), $5.74(\mathrm{~s}, 1 \mathrm{H}), 4.29-4.12(\mathrm{~m}, 4 \mathrm{H}), 3.52(\mathrm{~s}, 2 \mathrm{H}), 1.46(\mathrm{~s}, 9 \mathrm{H}), 1.24(\mathrm{t}, J=7.2 \mathrm{~Hz}, 6 \mathrm{H}) \quad \mathrm{ppm}$. ${ }^{13} \mathrm{C}\{1 \mathrm{H}\} \mathrm{NMR}\left(75 \mathrm{MHz}, \mathrm{CDCl}_{3}\right): \delta=167.6,154.0,143.2,138.1,136.7,133.6,128.20,128.18$, $128.1,127.9,127.6,123.9,122.0,80.4,78.2,67.2,62.7,38.0,28.4,14.1 \mathrm{ppm}$. IR (Neat) $v_{\max }=$ 3431, 2979, 1740, 1715, $1489 \mathrm{~cm}^{-1}$ HRMS (ESI): $\mathrm{m} / z[\mathrm{M}+\mathrm{Na}]^{+}$calcd for $\mathrm{C}_{32} \mathrm{H}_{35} \mathrm{NO}_{6} \mathrm{~S}_{2} \mathrm{Na}$ : 616.1804; found: 616.1805 . 


\section{2-(((9H-fluoren-9-yl)methoxy)carbonylamino)-3-(2,2-diphenylbenzo[d][1,3]dithiol-5-}

yl)propanoic acid (19a): To an ice-cold solution of malonate derivative $6 \mathbf{a}(247 \mathrm{mg}, 0.42 \mathrm{mmol})$ in THF: $\mathrm{H}_{2} \mathrm{O}(1: 1)(10 \mathrm{ml})$ was added $\mathrm{LiOH}^{\mathrm{H}} \mathrm{H}_{2} \mathrm{O}(120.38 \mathrm{mg}, 5.016 \mathrm{mmol})$, the mixture was allowed to reflux for $12 \mathrm{~h}$ in silicone oil bath. After completion of reaction (TLC monitoring), THF was removed, the remaining aqueous phase was first cooled to $0{ }^{\circ} \mathrm{C}$, acidified to $\mathrm{pH} 2$ with $0.1 \mathrm{~N} \mathrm{HCl}$ and then neutralised by adding solid $\mathrm{NaHCO}_{3}$ and diluted with $5 \mathrm{ml}$ of dioxane. A solution of Fmoc-OSu (282 mg, $0.84 \mathrm{mmol})$ in $7 \mathrm{ml}$ of dioxane was then added dropwise to the suspension at the same temperature and the resulting mixture was allowed to stir at RT for $12 \mathrm{~h}$. When the reaction was completed, the solvent was evaporated and the remaining aqueous phase was further acidified with $0.1 \mathrm{~N} \mathrm{HCl}$, extracted with EtOAc $(3 \times 5 \mathrm{ml})$. The combined organic layers were washed with water, followed by brine, dried over $\mathrm{Na}_{2} \mathrm{SO}_{4}$ and concentrated to afford the product 19a as a white foamy solid (194 $\mathrm{mg}, 75 \%$ yield), $\left(\mathrm{R}_{\mathrm{f}}=0.5, \mathrm{DCM} / \mathrm{MeOH}, 92: 8\right)$ which was used for esterification reaction without further purification. ${ }^{1} \mathrm{H}$ NMR $(300 \mathrm{MHz}$, $\left.\mathrm{CDCl}_{3}\right): \delta=7.74(\mathrm{~d}, J=7.5 \mathrm{~Hz}, 2 \mathrm{H}), 7.608-7.577(\mathrm{~m}, 4 \mathrm{H}), 7.52(\mathrm{~d}, J=6.6 \mathrm{~Hz}, 2 \mathrm{H}), 7.37(\mathrm{t}, J=$ $7.2 \mathrm{~Hz}, 2 \mathrm{H}), 7.30-7.19(\mathrm{~m}, 8 \mathrm{H}), 7.06(\mathrm{~d}, J=7.8 \mathrm{~Hz}, 2 \mathrm{H}), 6.98(\mathrm{~s}, 1 \mathrm{H}), 5.29(\mathrm{~d}, J=8.1 \mathrm{~Hz}, 1 \mathrm{H})$, $4.61(\mathrm{~d}, J=6.3 \mathrm{~Hz}, 1 \mathrm{H}), 4.43-4.29(\mathrm{~m}, 2 \mathrm{H}), 4.19-4.15(\mathrm{~m}, 1 \mathrm{H}), 3.09-2.93(\mathrm{~m}, 2 \mathrm{H}) \mathrm{ppm}$. ${ }^{13} \mathrm{C}\{1 \mathrm{H}\}$ NMR $\left(75 \mathrm{MHz}, \mathrm{CDCl}_{3}\right): \delta=175.6,155.9,143.8,143.7,143.1,141.4,138.5,136.8$, $133.9,127.8,127.2,125.2,125.1,123.0,122.3,120.1,78.2,67.2,54.6,47.2,37.4$ ppm. IR (Neat) $v_{\max }=3273,1737,1699,1655,1450,891 \mathrm{~cm}^{-1}$. HRMS (ESI): $\mathrm{m} / z[\mathrm{M}+\mathrm{H}]^{+}$calcd for $\mathrm{C}_{37} \mathrm{H}_{30} \mathrm{NO}_{4} \mathrm{~S}_{2}: 616.1611$; found: 616.1612 .

\section{2-(((9H-fluoren-9-yl)methoxy)carbonylamino)-3-(2,2-diphenylbenzo-[d][1,3]dithiol-4-yl)}

propanoic acid (19b): Starting from $6 \mathbf{b}, \mathbf{1 9 b}$ was synthesized following the procedure of 19a. 19b was obtained as a white foamy solid product. Yield $72 \%,\left(\mathrm{R}_{\mathrm{f}}=0.5, \mathrm{DCM} / \mathrm{MeOH}, 92: 8\right) .{ }^{1} \mathrm{H}$ 
NMR $\left(300 \mathrm{MHz}, \mathrm{CDCl}_{3}\right): \delta=7.71(\mathrm{~d}, J=7.5 \mathrm{~Hz}, 2 \mathrm{H}), 7.60(\mathrm{t}, J=8.8 \mathrm{~Hz}, 4 \mathrm{H}), 7.48(\mathrm{~d}, J=7.2$ $\mathrm{Hz}, 2 \mathrm{H}), 7.34(\mathrm{t}, J=7.3 \mathrm{~Hz}, 2 \mathrm{H}), 7.23-7.13(\mathrm{~m}, 8 \mathrm{H}), 7.07(\mathrm{~d}, J=7.5 \mathrm{~Hz}, 1 \mathrm{H}), 6.91(\mathrm{t}, J=7.5$ $\mathrm{Hz}, 1 \mathrm{H}), 6.84(\mathrm{~m}, 1 \mathrm{H}), 5.34(\mathrm{~d}, J=7.5 \mathrm{~Hz}, 1 \mathrm{H}), 4.68(\mathrm{~d}, J=5.4 \mathrm{~Hz}, 1 \mathrm{H}), 4.36-4.23(\mathrm{~m}, 2 \mathrm{H})$, $4.11(\mathrm{~m}, 1 \mathrm{H}), 3.26-3.01(\mathrm{~m}, 2 \mathrm{H}) \mathrm{ppm} .{ }^{13} \mathrm{C}\{1 \mathrm{H}\}$ NMR $\left(75 \mathrm{MHz}, \mathrm{CDCl}_{3}\right): \delta=175.8,156.0,143.9$, $143.7,143.2,142.6,141.3,138.6,130.8,128.1,127.9,127.9,127.8,127.4,127.2,126.4,125.3$, 125.2, 121.2, 120.0, 77.3 , 67.4, 54.0, 47.1, 38.1 ppm. IR (Neat) $v_{\max }=3068,2928,1714,1508$, 1447, $740 \mathrm{~cm}^{-1}$. HRMS (ESI): $\mathrm{m} / z[\mathrm{M}+\mathrm{Na}]^{+}$calcd for $\mathrm{C}_{37} \mathrm{H}_{29} \mathrm{NO}_{4} \mathrm{~S}_{2} \mathrm{Na}$ : 638.1436; found: 638.1438.

Methyl-2-(((9H-fluoren-9-yl)methoxy)carbonylamino)-3-(2,2-diphenylbenzo[d][1,3]dithiol-

5-yl)propanoate (1a): To a suspended solution of compound 19a (212 $\mathrm{mg}, 0.34 \mathrm{mmol})$ in anhydrous DMF (3 ml), $\mathrm{K}_{2} \mathrm{CO}_{3}(94 \mathrm{mg}, 0.68 \mathrm{mmol})$ was added portion wise at $0{ }^{\circ} \mathrm{C}$. The mixture was stirred at RT for $10 \mathrm{~min}$ and again cooled to $0{ }^{\circ} \mathrm{C}$, treated with $\mathrm{CH}_{3} \mathrm{I}(0.084 \mathrm{ml}, 1.36 \mathrm{mmol})$ and allowed to stir at RT for $12 \mathrm{~h}$. After completion of reaction, the reaction mixture was quenched with $\mathrm{NH}_{4} \mathrm{Cl}(5 \mathrm{ml})$, extracted with EtOAc $(3 \times 5 \mathrm{ml})$. The organic layers were combined, washed with brine, dried over $\mathrm{Na}_{2} \mathrm{SO}_{4}$ and concentrated in vacuo. The crude product was purified by column chromatography using ethyl acetate-petroleum ether (1:6) on silica gel to afford 1a as a white solid (167 $\mathrm{mg}, 78 \%$ yield $),\left(\mathrm{R}_{\mathrm{f}}=0.5\right.$, Pet-ether/EtOAc, 75:25). ${ }^{1} \mathrm{H}$ NMR $\left(300 \mathrm{MHz}, \mathrm{CDCl}_{3}\right): \delta=7.77(\mathrm{~d}, J=7.5 \mathrm{~Hz}, 2 \mathrm{H}), 7.62(\mathrm{~d}, J=10.8 \mathrm{~Hz}, 4 \mathrm{H}), 7.57(\mathrm{~m}, 2 \mathrm{H}), 7.40(\mathrm{t}$, $J=7.5 \mathrm{~Hz}, 2 \mathrm{H}), 7.35-7.09(\mathrm{~m}, 8 \mathrm{H}), 7.11(\mathrm{~d}, J=7.8 \mathrm{~Hz}, 1 \mathrm{H}), 6.96(\mathrm{~s}, 1 \mathrm{H}), 6.75(\mathrm{~d}, J=7.8 \mathrm{~Hz}$, $1 \mathrm{H}), 5.24(\mathrm{~d}, J=8.1 \mathrm{~Hz}, 1 \mathrm{H}), 4.61(\mathrm{~m}, 1 \mathrm{H}), 4.47-4.32(\mathrm{~m}, 2 \mathrm{H}), 4.21(\mathrm{~m}, 1 \mathrm{H}), 3.65(\mathrm{~s}, 3 \mathrm{H})$, 2.99(d, $J=5.7 \mathrm{~Hz}, 2 \mathrm{H}) \mathrm{ppm} .{ }^{13} \mathrm{C}\{1 \mathrm{H}\} \mathrm{NMR}\left(75 \mathrm{MHz}, \mathrm{CDCl}_{3}\right): \delta=171.8,155.6,143.9,143.8$, $143.1,141.4,138.5,136.8,134.0,128.5,128.2,128.2,127.9,127.8,127.2,127.1,127.0,126.9$, $125.2,125.1,123.7,123.0,120.1,67.1,54.8,52.4,47.3,38.0 \mathrm{ppm}$. IR (Neat) $v_{\max }=3333,3064$, 
2951, 1723, 1521, 1445, 1213, $740 \mathrm{~cm}^{-1}$. HRMS (ESI): $\mathrm{m} / z[\mathrm{M}+\mathrm{Na}]^{+}$calcd for $\mathrm{C}_{38} \mathrm{H}_{31} \mathrm{NO}_{4} \mathrm{~S}_{2} \mathrm{Na}$ : 652.1592; found: 652.1593 .

Methyl 2-(((9H-fluoren-9-yl) methoxy) carbonylamino)-3-(2,2-diphenylbenzo[d][1,3]dithiol4-yl)propanoate (1b): Starting from compound $\mathbf{1 9 b}(100 \mathrm{mg}, 0.162 \mathrm{mmol})$, $1 \mathbf{b}$ was synthesized following the procedure of 1a. 1b was obtained as a white solid product. Yield $77 \%(78 \mathrm{mg}),\left(\mathrm{R}_{\mathrm{f}}\right.$ $=0.5$, Pet-ether/EtOAc, 75:25). ${ }^{1} \mathrm{H}$ NMR $\left(300 \mathrm{MHz}, \mathrm{CDCl}_{3}\right): \delta=7.76(\mathrm{~d}, J=7.5 \mathrm{~Hz}, 2 \mathrm{H})$, 7.66-7.60 (m, 4H), $7.54(\mathrm{~d}, J=7.2 \mathrm{~Hz}, 2 \mathrm{H}), 7.39(\mathrm{~m}, 2 \mathrm{H}), 7.30-7.18(\mathrm{~m}, 8 \mathrm{H}), 7.12(\mathrm{~d}, J=7.5$ $\mathrm{Hz}, 1 \mathrm{H}), 6.97(\mathrm{~m}, 1 \mathrm{H}), 6.82(\mathrm{~d}, J=7.5 \mathrm{~Hz}, 1 \mathrm{H}), 5.34(\mathrm{~d}, J=7.2 \mathrm{~Hz}, 1 \mathrm{H}), 4.72(\mathrm{q}, J=7.0 \mathrm{~Hz}$, $1 \mathrm{H}), 4.41-4.15(\mathrm{~m}, 2 \mathrm{H}), 4.17(\mathrm{~m}, 1 \mathrm{H}), 3.69(\mathrm{~s}, 3 \mathrm{H}), 3.22-3.04(\mathrm{~m}, 2 \mathrm{H}) \mathrm{ppm} .{ }^{13} \mathrm{C}\{1 \mathrm{H}\} \mathrm{NMR}(75$ $\left.\mathrm{MHz}, \mathrm{CDCl}_{3}\right): \delta=172.0,155.7,144.0,143.8,143.3,142.7,141.3,138.7,138.6,130.7,128.5$, $128.2,128.2,127.9,127.8,127.3,127.2,126.9,126.3,125.3,125.2,121.2,120.0,67.2,54.0$ 52.6, 47.2, $38.7 \mathrm{ppm}$. IR (Neat) $v_{\max }=3418,3068,2925,1723,1521,1447,740 \mathrm{~cm}^{-1}$. HRMS (ESI): $m / z[\mathrm{M}+\mathrm{Na}]^{+}$calcd for $\mathrm{C}_{38} \mathrm{H}_{31} \mathrm{NO}_{4} \mathrm{~S}_{2} \mathrm{Na}$ : 652.1592; found: 652.1593 .

Optical resolution by preparative chiral HPLC: Chiral amino acids 1a and $\mathbf{1 b}$ were analyzed and purified on Chiralpak IF and Chiralpak ID columns. The two fractions collected were analyzed by analytical chiral HPLC, polarimeter and ECD and VCD.

Chromatographic conditions for 1a: Compound 1a was pre-purified on a preparative Chiralpak ID to remove $\sim 10 \%$ of unidentified impurities. Then $380 \mathrm{mg}$ of the purified racemic were dissolved in $8 \mathrm{~mL}$ of a mixture $\mathrm{CH}_{2} \mathrm{Cl}_{2} /$ ethanol (1/1). It was injected on Chiralpak IF (250 $\times 10 \mathrm{~mm}$ ) in $160 \times 50 \mu \mathrm{L}$ stacked injections (every $4.2 \mathrm{~min}$ ), using hexane/iPrOH/DCM $(80 / 10 / 10)$ as mobile phase with flow-rate $5 \mathrm{~mL} / \mathrm{min}$. and detected with an UV detector at 280 nm. 2 fractions were collected and analyzed on analytical Chiralpak IF using 
heptane/iPrOH/DCM (80/10/10) as isocratic eluant: 1a- $R$ : $147 \mathrm{mg}, \mathrm{Rt}=9.8(\mathrm{ee}>99.5 \%),[\alpha]_{\mathrm{D}}{ }^{25}$ $\left(\mathrm{CHCl}_{3}, \mathrm{c}=0.89\right)=-29$. Crystals could be grown by slow evaporation at $4^{\circ} \mathrm{C}$ of a solution containing $110 \mathrm{mg}$ of the first eluted enantiomer for $\mathbf{1 a}$ in $\mathrm{CH}_{2} \mathrm{Cl}_{2} / \mathrm{EtOH}(1: 1)$ in the presence of traces of pentane and water. The structure was deposited on the CCDC (CCDC 2035077). 1a-S: $139 \mathrm{mg}, \mathrm{Rt}=11.48 \mathrm{~min}(\mathrm{ee}>99.5 \%),[\alpha]_{\mathrm{D}}^{25}\left(\mathrm{CHCl}_{3}, \mathrm{c}=0.90\right)=+29$. Crystals could be grown in similar conditions than for $\mathbf{1 a -} \boldsymbol{R}$, however, the needles were smaller and the structure could not be solved.

Chromatographic conditions for 1b: About $320 \mathrm{mg}$ of racemic compound $\mathbf{1 b}$ was dissolved in $2 \mathrm{~mL}$ of DCM, injected on Chiralpak ID $(250 \times 10 \mathrm{~mm})$ in $40 \times 50 \mu \mathrm{L}$ stacked injections (every $3.8 \mathrm{~min})$, using hexane/iPrOH/DCM (70/10/20) as mobile phase with flow-rate $5 \mathrm{~mL} / \mathrm{min}$, and detected with an UV detector at $290 \mathrm{~nm} .2$ fractions were collected and analyzed on analytical Chiralpak ID using Heptane/iPrOH/ $\mathrm{CH}_{2} \mathrm{Cl}_{2}$ (70/10/20) as isocratic eluant: (1) unidentified: 145 $\mathrm{mg}, \mathrm{Rt}=5.51 \mathrm{~min}(\mathrm{ee}>99 \%),[\alpha]_{\mathrm{D}}^{25}\left(\mathrm{CHCl}_{3}, \mathrm{c}=1.16\right)=+10.5$. $(2)$ unidentified: $135 \mathrm{mg}, \mathrm{Rt}=$ $6.48 \min (\mathrm{ee}>99.5 \%),[\alpha]_{\mathrm{D}}^{25}\left(\mathrm{CHCl}_{3}, \mathrm{c}=0.95\right)=-10.5$.

\section{2-(((9H-fluoren-9-yl)methoxy)carbonylamino)-3-(2,2-diphenylbenzo[d][1,3]dithiol-5-}

yl)propanoic acid (19a): The compound $1 \mathbf{a}(84 \mathrm{mg}, 0.133 \mathrm{mmol})$ was dissolved in isopropanol $(2.5 \mathrm{ml})$ and THF $(0.8 \mathrm{ml}) . \mathrm{CaCl}_{2}(237 \mathrm{~g}, 2.13 \mathrm{mmol})$ was added. Separately, LiOH.H $\mathrm{H}_{2} \mathrm{O}(22.4$ $\mathrm{mg}, 0.533 \mathrm{mmol})$ was dissolved in $\mathrm{H}_{2} \mathrm{O}(1.1 \mathrm{ml})$. The aqueous solution was then added to the reaction mixture and the cloudy white solution was stirred for $2.5 \mathrm{~h}$. The organic solvents were removed under reduced pressure, and the resulting residue was taken up in $10 \%$ potassium carbonate $\left(\mathrm{K}_{2} \mathrm{CO}_{3}\right)(5 \mathrm{ml})$ as a cloudy white suspension. The aqueous layer was partitioned in $\mathrm{Et}_{2} \mathrm{O}(2 \times 5 \mathrm{ml})$ to remove the Fmoc deprotection side products (if any), after which it was 
acidified to $\mathrm{pH} 2$ with dilute $\mathrm{HCl}$. It was then extracted with EtOAc $(30 \mathrm{ml})$. The organic layers were dried over $\mathrm{Na}_{2} \mathrm{SO}_{4}$, and concentrated to obtain 19a as a white foamy solid in $98 \%$ yield (80.4 $\mathrm{mg}, 0.131 \mathrm{mmol}$ ). The ${ }^{1} \mathrm{H}$ NMR spectrum recorded on the product was matching that for 19a reported above. This method was also used to deprotect single enantiomers $1 \mathbf{a}-\boldsymbol{R}$ and $\mathbf{1 a}-\boldsymbol{S}$, respectively leading to enantiopure $19 a-R$ and $19 a-S$.

\section{2-(((9H-fluoren-9-yl)methoxy)carbonylamino)-3-(2,2-diphenylbenzo-[d][1,3]dithiol-4-}

yl)propanoic acid (19b): Compound 19b was obtained from $1 \mathbf{b}$ (91 $\mathrm{mg}, 0.144 \mathrm{mmol}$ ) in 90\% yield ( $80 \mathrm{mg}, 0.130 \mathrm{mmol})$. The procedure was same as the synthesis of 19a.

Methyl 2-((((9H-fluoren-9-yl)methoxy)carbonyl)amino)-3-(3,4-dimercaptophenyl)propano-ate (21a): $\mathrm{HBF}_{4} 35$ wt. \% in $\mathrm{H}_{2} \mathrm{O}(0.3 \mathrm{~mL}, 1.225 \mathrm{mmol})$ was added at $\mathrm{RT}$ to a suspension of mercury (II) oxide $(60 \mathrm{mg}, 0.277 \mathrm{mmol})$ in freshly distilled THF (2 mL). Compound 19a (110 $\mathrm{mg}, 0.175 \mathrm{mmol})$ was dissolved in THF $(3 \mathrm{~mL})$ and it was added to the stirring reaction mixture, in one portion. The reaction was moderately exothermic and the color of the solution changed from orange to colorless solution. After completion of the reaction (TLC monitoring), THF was evaporated to afford a sticky material. Addition of water $(3 \times 25 \mu \mathrm{L})$ to this crude mixture followed by decantation yielded a precipitate. The precipitate was then washed with Petether/EtOAc (90:10) and the organic layer was decanted. The trituration procedure was repeated until the benzophenone was completely removed (TLC monitoring in Pet-ether/EtOAc, 95:5) and dried in vacuo to get a pale yellow solid. The solid was suspended in dry EtOAc (5 mL) in a strictly anaerobic atmosphere (Schlenk line) and $\mathrm{H}_{2} \mathrm{~S}$ (g) (!!! Caution !!! $\mathrm{H}_{2} \mathrm{~S}$ is a highly toxic compound and should be handled with care) was flown over for $4 \mathrm{~h}$ imparting a color change from yellow to orange then black (a black precipitate formed over the course of the initial 15 
min) (Figure S17). The suspension was then centrifuged. The supernatant solution was separated by decantation and the residual solid particles were further washed with $\mathrm{MeCN}$ and centrifuged 2-3 times. Finally, the collected supernatants were combined and dried in vacuo to get a yellowish solid product which was directly submitted for characterization. Isolated yield of 21a is $44 \%$ (36 mg). ${ }^{1} \mathbf{H}$ NMR (400 MHz, $\left.\mathrm{CDCl}_{3}\right) \delta=7.83-7.67(\mathrm{~m}, 2 \mathrm{H}), 7.65-7.46(\mathrm{~m}, 2 \mathrm{H})$, 7.45-7.03 (m, 6H), 6.94-6.65 (m, 1H), 5.63-5.18 (m, 1H), 4.74-4.52 (m, 1H), 4.50-4.28 (m, 2H), 4.27-4.10 (m, 1H), 3.83-3.54 (m, 3H), 3.18-2.73 (m, 2H) ppm. ${ }^{13} \mathbf{C}\{\mathbf{1 H}\} \mathbf{N M R}(75 \mathrm{MHz}$, $\left.\mathrm{CDCl}_{3}\right) \delta=171.6,155.5,143.7,143.6,141.2,134.7,131.7,131.6,131.4,129.6,127.7,127.0$ 124.9, 119.9, 66.9, 54.5, 52.4, 47.1, $37.5 \mathrm{ppm}$. IR (Neat) $v_{\max }=3016,2951,2555,1708,1505$, $1448,1343,1213,1105,1054,753 \mathrm{~cm}^{-1}$. HRMS (ESI): $\mathrm{m} / \mathrm{z}[\mathrm{M}+\mathrm{Na}]^{+}$calcd for $\mathrm{C}_{25} \mathrm{H}_{23} \mathrm{NO}_{4} \mathrm{~S}_{2} \mathrm{Na}$ $=488.0966 ;$ found 488.0964 .

\section{Methyl 2-((((9H-fluoren-9-yl)methoxy)carbonyl)amino)-3-(2,3-dimercaptophenyl)propano-}

-ate (21b): Starting from compound 19b (110 mg, $0.175 \mathrm{mmol})$, 21b was synthesized following the procedure of 21a. Isolated yield of $\mathbf{2 1 b}$ was $43 \%(35 \mathrm{mg}) .{ }^{1} \mathbf{H} \mathbf{~ N M R ~}\left(300 \mathrm{MHz}, \mathrm{CDCl}_{3}\right) \delta=$ 7.74 (br. s, 2H), 7.55 (br. s, 2H), 7.45-7.14 (m, 5H), 7.13-6.92 (m, 1H), 6.91-6.62 (m, 1H), 5.44 (br. s, $1 \mathrm{H}), 4.90-4.57(\mathrm{~m}, 1 \mathrm{H}), 4.47-4.23(\mathrm{~m}, 2 \mathrm{H}), 4.24-4.04(\mathrm{~m}, 1 \mathrm{H}), 3.73(\mathrm{~s}, 3 \mathrm{H}), 3.53-3.24$ $(\mathrm{m}, 1 \mathrm{H}), 3.24-2.87(\mathrm{~m}, 1 \mathrm{H}) \mathrm{ppm} .{ }^{13} \mathbf{C}\{\mathbf{1 H}\} \mathbf{N M R}\left(75 \mathrm{MHz}, \mathrm{CDCl}_{3}\right) \delta=172.2,155.6,143.7$ 141.2, 139.3, 129.8, 128.7, 127.7, 127.0, 126.3, 125.0, 122.4, 119.9, 113.8, 67.0, 54.1, 52.4, 47.0, 37.5 ppm. IR (Neat) $v_{\max }=3334,3017,2952,2549,1719,1699,1576,1514,1477,1462,1446$, 1339, 1213, 1104, 1051, $752 \mathrm{~cm}^{-1}$. HRMS (ESI): $\mathrm{m} / \mathrm{z}[\mathrm{M}+\mathrm{Na}]^{+}$calcd for $\mathrm{C}_{25} \mathrm{H}_{23} \mathrm{NO}_{4} \mathrm{~S}_{2} \mathrm{Na}=$ 488.0966; found 488.0965. 
Synthesis of $\mathrm{H}_{2} \mathrm{~N}-\mathrm{Tyr}-\mathrm{Leu}-\mathrm{Ser}-\mathrm{Ala}-\mathrm{Phe}-\mathrm{His}-\mathrm{Ala}-\mathrm{Glu}-\mathrm{Phe}^{3,4-\mathrm{dt}}\left(\mathrm{CPh}_{2}\right)-\mathrm{Gly}-\mathrm{CONH} \mathrm{N}_{2}(23)$ : The

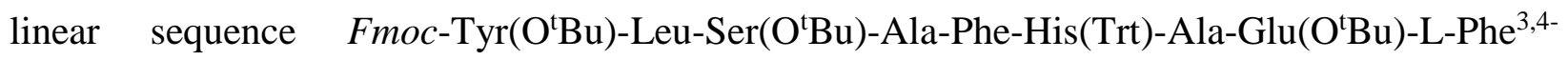
${ }^{\mathrm{dt}}\left(\mathrm{CPh}_{2}\right)$-Gly-resin was assembled on a rink amide resin $(0.1 \mathrm{mmol}, 0.59 \mathrm{mmol} / \mathrm{g}, 169 \mathrm{mg})$ by mixed manual and automated solid-phase peptide synthesis. The resin was pre-swollen in DMF at room temperature for $30 \mathrm{~min}$. The $F m o c$ - deprotections were performed on the synthesizer at room temperature in two successive steps of 3 and $10 \mathrm{~min}$, each involving $4.5 \mathrm{~mL}$ of $20 \%$ piperidine in DMF. The first peptide coupling (Gly) was performed on the automated microwave synthesizer at $75^{\circ} \mathrm{C}$ for $5 \mathrm{~min}$ after addition of Fmoc-Gly-COOH (148 $\left.\mathrm{mg}, 0.5 \mathrm{mmol}\right)$ in DMF (1.72 mL), HBTU (186 mg, $0.49 \mathrm{mmol})$ in DMF (0.82 mL), and DIEA (174 $\mu \mathrm{L}, 1.0 \mathrm{mmol})$ in NMP $(0.5 \mathrm{~mL})$. The second coupling (L-Phe $\mathrm{S}^{3,4-\mathrm{dt}}$ ) was performed manually at $25^{\circ} \mathrm{C}$ for $60 \mathrm{~min}$ after addition of 2 equivalents of $F m o c-L-P h e^{3,4-d t}\left(\mathrm{CPh}_{2}\right)-\mathrm{COOH}, \mathbf{1 9 a}-\mathrm{S},(0.2 \mathrm{mmol}, 123 \mathrm{mg})$ in DMF (0.8 mL), HBTU (76 mg, $0.2 \mathrm{mmol})$ in DMF $(0.33 \mathrm{~mL})$, and DIEA (67 $\mu \mathrm{L}, 0.4 \mathrm{mmol})$ in NMP $(0.2 \mathrm{~mL})$. A Kaiser test indicated that the reaction did not reach completion and this coupling step was repeated using extra 1.1 equivalents of $\mathbf{1 9 a}-\mathbf{S}$ (same protocol as before). The following coupling steps were performed on the automated micro-wave synthesizer following the same protocol as for Gly, except the His coupling, which was performed at $50{ }^{\circ} \mathrm{C}$ for 6.5 min. The final peptide was first Fmoc deprotected and afterwards simultaneously cleaved from the resin and side-chain deprotected (except for the dithioketal function). For this, the aliquot of resin was treated with $2 \times 5 \mathrm{~mL}$ of $20 \%$ piperidine in DMF for $10 \mathrm{~min}$. After each treatment, the solution was filtered out and then the resin was successively washed with $5 \times 5 \mathrm{~mL}$ DMF and $5 \times$ $5 \mathrm{~mL}$ DCM. Then, the resin was treated with $5 \mathrm{~mL}$ of TFA/TIS/water (95/2.5/2.5) cocktail for 2 hours. The volume of solution was decreased by flushing $\mathrm{N}_{2}$ at the top of the solution. The crude peptide was precipitated by the addition of cold $\mathrm{Et}_{2} \mathrm{O}$ and further decanted by centrifugation. The 
solid was triturated in cold diethyl ether and decanted by centrifugation twice. The peptide was redissolved in a water/acetonitrile/TFA (50/50/0.1) mixture and lyophilized to afford an offwhite feather-like solid product (60 mg, 44\%). ${ }^{1} \mathrm{H}$ NMR (300 MHz, $\mathrm{D}_{2} \mathrm{O} / \mathrm{CD}_{3} \mathrm{OD}(1 / 1)$, water presaturation): $\delta=8.69(\mathrm{~s}, 1 \mathrm{H}), 7.55(\mathrm{~m}, 4 \mathrm{H}), 7.34-7.25(\mathrm{~m}, 7 \mathrm{H}), 7.25-7.07(\mathrm{~m}, 9 \mathrm{H}), 6.97(\mathrm{~d}, J$ $=7.9 \mathrm{~Hz}, 1 \mathrm{H}), 6.85(\mathrm{~d}, J=8.2 \mathrm{~Hz}, 2 \mathrm{H}), 4.63-4.41(\mathrm{~m}, 4 \mathrm{H}), 4.33-4.13(\mathrm{~m}, 4 \mathrm{H}), 4.04-3.68(\mathrm{~m}$, 5H), 3.30-2.94 (m, 7H), $2.78(\mathrm{~m}, 1 \mathrm{H}), 2.21(\mathrm{~m}, 2 \mathrm{H}), 1.83(\mathrm{~m}, 2 \mathrm{H}), 1.63(\mathrm{~m}, 3 \mathrm{H}), 1.37(\mathrm{~d}, J=7.2$ $\mathrm{Hz}, 3 \mathrm{H}), 1.32(\mathrm{~d}, J=7.2 \mathrm{~Hz}, 3 \mathrm{H}), 0.91(\mathrm{~m}, 6 \mathrm{H}) . \mathrm{HRMS}(\mathrm{ESI}): \mathrm{m} / \mathrm{z}[\mathrm{M}+2 \mathrm{H}]^{2+}$ calcd for $\mathrm{C}_{68} \mathrm{H}_{83} \mathrm{~N}_{13} \mathrm{O}_{14} \mathrm{~S}_{2}: 684.7806$; found: 684.7803 .

Synthesis of $\mathrm{H}_{2} \mathrm{~N}-\mathrm{Tyr}-$ Leu-Ser-Ala-Phe-His-Ala-Glu--Phe ${ }^{3,-d t}-\mathrm{Gly}_{-} \mathrm{CONH}_{2}$ (24): The peptide 23 (10.4 mg, $7 \mu \mathrm{mol})$ dissolved in $1 \mathrm{~mL}$ dry THF was treated with $\mathrm{HBF}_{4} 35$ wt. \% in $\mathrm{H}_{2} \mathrm{O}(12$ $\mu \mathrm{L}, 0.047 \mathrm{mmol})$ followed by addition of mercury (II) oxide (2.27 $\mathrm{mg}, 0.01 \mathrm{mmol})$ and was stirred for $2 \mathrm{~h}$. THF was evaporated to dryness. Water $(15 \mu \mathrm{L})$ was then added and the aqueous layer was decanted carefully affording a pale yellow precipitate. Next, the precipitate was washed with Pet-ether/EtOAC (90:10) to remove the benzophenone side-product and dried in vacuo. The solid mass was suspended in dry EtOAc/MeOH (1.5 mL using ratio 95:5) under argon balloon and $\mathrm{H}_{2} \mathrm{~S}$ was flown for $15 \mathrm{~min}$. The reaction mixture was stirred for an additional $4 \mathrm{~h}$ resulting into the formation of a black precipitate. The mixture was then centrifuged and filtered. The black precipitate was washed again with $\mathrm{EtOAc} / \mathrm{MeOH}(2 \times 1.5 \mathrm{~mL}$ using ratio 95:5). The filtered solution was removed in vacuo to obtain a black solid peptide. The methanolic solution of peptide was then dialyzed in presence of DTT (3 equiv) for $48 \mathrm{~h}$ to get a white solid product 24 (3.1 mg, 37\%). Analytical RP-HPLC (SPOLAR C18 S5 column, $0.8 \mathrm{~mL}$ $\min ^{-1}$, gradient $50-80 \% \mathrm{~B}$ in A over 25 min with $\mathrm{A}-$ water $+0.1 \%$ TFA and $\mathrm{B}-$ water/MeCN $(10 / 90)+0.1 \% \mathrm{TFA}) \mathrm{R}_{\mathrm{T}}=4.5 \mathrm{~min} . \mathbf{I R}$ (Neat) $v_{\max }=3332,2948,2535,1695,1577,1477,1462$, 
1410, 1336, 1225, 1050, 1019, $739 \mathrm{~cm}^{-1}$. MALDI-TOF MS: $\mathrm{m} / \mathrm{z}[\mathrm{M}+\mathrm{Na}]^{+}$calcd for $\mathrm{C}_{55} \mathrm{H}_{73} \mathrm{~N}_{13} \mathrm{O}_{14} \mathrm{~S}_{2} \mathrm{Na}=1226.4739$; found 1230.220. $[\mathrm{M}+\mathrm{K}]^{+}$calcd for $\mathrm{C}_{55} \mathrm{H}_{73} \mathrm{~N}_{13} \mathrm{O}_{14} \mathrm{~S}_{2} \mathrm{~K}=$ 1242.4478; found 1247.521. HRMS (ESI): $\mathrm{m} / \mathrm{z}[\mathrm{M}+\mathrm{H}]^{+}$calcd for dithiete compound $\mathrm{C}_{55} \mathrm{H}_{72} \mathrm{~N}_{13} \mathrm{O}_{14} \mathrm{~S}_{2}$ 1202.4757; found 1202.4755.

Vibrational Circular Dichroism: Infrared (IR) and vibrational circular dichroism (VCD) spectra were recorded on a Bruker PMA 50 accessory coupled to a Vertex70 Fourier transform infrared spectrometer. A photoelastic modulator (Hinds PEM 90) set at 1/4 retardation was used to modulate the handedness of the circular polarized light at $50 \mathrm{kHz}$. Demodulation was performed by a lock-in amplifier (SR830 DSP). An optical low-pass filter $\left(<1800 \mathrm{~cm}^{-1}\right)$ before the photoelastic modulator was used to enhance the signal/noise ratio. A transmission cell equipped with $\mathrm{BaF}_{2}$ windows and of $200 \mu \mathrm{m}$ of optical pathlength was used. Solutions with a concentration of $0.07 \mathrm{~mol} \mathrm{~L}^{-1}$ (for the enantiomers of 1a) and $0.05 \mathrm{~mol} \cdot \mathrm{L}^{-1}$ (for the enantiomers of $1 \mathbf{b})$ were prepared by dissolving the solid samples in $\mathrm{CD}_{2} \mathrm{Cl}_{2}$. The VCD spectra of the pure enantiomers of (first eluted)-1a and (second eluted)-1a on one hand, and of (first eluted)-1b and (second eluted)-1b on the other hand were measured at RT and the baseline of the spectra were corrected using the standard procedure of the half-substraction of the spectra of each enantiomer. For each individual spectrum, about 12000 scans were averaged at $4 \mathrm{~cm}^{-1}$ resolution (corresponding to 3 hours measurement time). For IR absorption spectra, the cell filled with $\mathrm{CD}_{2} \mathrm{Cl}_{2}$ served as a reference. The spectra are presented without smoothing and further data processing.

Computational Details for the calculations of the IR/VCD spectra: Prior to the calculations of the IR and VCD spectra, a conformational analysis has been performed using a stochastic 
exploration (annealing) of the potential energy surface (SEP) of the $(R)$ enantiomer of $\mathbf{1 a}$ and of 1b. The annealing was done at semi-empirical level PM3, starting from a geometry optimized using density functional theory (DFT) with B3LYP functional and 6-311G(d,p) basis set and including solvent $\left(\mathrm{CD}_{2} \mathrm{Cl}_{2}\right)$ effects with a polarizable continuum model (SMD). During the annealing, only the dihedral angles have been relaxed, the bonds lengths and the valences angles were kept frozen. This step, allowed us to find 69 and 65 conformers, respectively for $\mathbf{1 a -} \boldsymbol{R}$ and 1b-R, among which the 30 and 20 most stable have been fully optimized using SMD $\left(\mathrm{CD}_{2} \mathrm{Cl}_{2}\right) / \mathrm{B} 3 \mathrm{LYP} / 6-311 \mathrm{G}(\mathrm{d}, \mathrm{p})$ level. Using the geometries that have converged, we calculated Boltzmann population in $\mathrm{CD}_{2} \mathrm{Cl}_{2}$ in table $\mathbf{S 7}$ for $\mathbf{1 a}-\boldsymbol{R}$ and $\mathbf{S 8}$ for $\mathbf{1 b}-\boldsymbol{R}$. For the construction of averaged IR and VCD spectra, only conformations with a Boltzmann population $>3 \%$ have been used. The vibrational frequencies IR absorption and VCD intensities were calculated using the same theoretical level as for geometry optimization $\operatorname{SMD}\left(\mathrm{CH}_{2} \mathrm{Cl}_{2}\right) / \mathrm{B} 3 \mathrm{LYP} / 6-311 \mathrm{G}(\mathrm{d} \mathrm{p})$. Computed harmonic frequencies have been calibrated using a standard scaling factor of 0.98 . Indeed, because of the incomplete treatment of electron correlation, harmonic approximation and basis set truncation effects, the calculated frequencies generally overestimate. In order to improve the agreement between the calculated and measured frequencies, the computed harmonic frequencies are usually scaled for comparison. IR absorption and VCD averaged spectra were constructed from calculated dipole and rotational strengths assuming Lorentzian band shape with a half-width at half maximum of $8 \mathrm{~cm}^{-1}$. All calculations were performed using Ampac $10^{31}$ (simulated annealing) and Gaussian 16 package. ${ }^{32}$

General procedure for XPS analysis: The X-ray photoemission spectroscopy (XPS) measurements were carried out using an Omicron electron spectrometer, equipped with a Scienta omicron sphera analyzer and $\mathrm{Al} K \alpha$ monochromatic source with an energy resolution of $0.5 \mathrm{eV}$. 
The samples were prepared in Si surfaces. Before collecting the spectra, the sample surface was sputtered with argon ion bombardment for each of these samples to remove any kind of surface oxidization effect and the presence of environmental carbons in the pelletized samples.

Supporting Information Available: Copies of NMR $\left({ }^{1} \mathrm{H},{ }^{13} \mathrm{C}\right)$ spectra of all the new compounds along with X-ray structure, IR, VCD and CD spectra, HPLC chromatogram and HRMS data of relevant compounds are provided. This material is available free of charge via the Internet at http://pubs.acs.org.

\section{ACKNOWLEDGEMENT}

S.S. and M.R. thanks Indo-French Centre for promotion of advanced research (CEFIPRA) for financial support by a grant [IFC/A/5105-2/2014/1060]. K. C. G and I. B. are thankful to CSIR, New Delhi for their fellowships. E.O. and O.I. thanks the ANR for funding (ANR16-CE290010). We thank Nicolas Vanthuyne and Muriel Albalat at Plateforme de chromatographie chirale et de stéréochimie dynamique, Aix Marseille Université and Michel Giorgi at Spectropole for X-ray measurements and structure determination. Standardization of amino acid synthesis was performed by K. C. G. and I. B. Thiol deprotection of amino acids and decapeptide and mass analysis were performed by I.B.

\section{REFERENCES}

(1) Poole, L. B. The basics of thiols and cysteines in redox biology and chemistry. Free Radic. Biol. Med. 2015, 80, 148-157.

(2) For Cysteine SH in stability and conformation, see: (a) Antoniou, A. I.; Pepe, D. A.; Aiello, D.; Siciliano, C.; Athanassopoulos, C. M. Chemoselective Protection of Glutathione in the 
Preparation of Bioconjugates: The Case of Trypanothione Disulfide. J. Org. Chem. 2016, 81, 4353-4358; (b) Craik, D. J.; Daly, N. L.; Waine, C. The cystine knot motif in toxins and implications for drug design. Toxicon 2001, 39, 43-60; (c) Hodgson, D. R. W.; Sanderson, J. M. The synthesis of peptides and proteins containing non-natural amino acids. Chem. Soc. Rev. 2004, 33, 422-430; (d) Matsumura, M.; Signor, G.; Matthews, B. W. Substantial increase of protein stability by multiple disulphide bonds. Nature 1989, 342, 291-293; (e) Muttenthaler, M.; B. Akondi, K.; F. Alewood, P. Structure-Activity Studies on Alpha-Conotoxins. Curr. Pharm. Des. 2011, 17, 4226-4241.

(3) (a) Camarero, J. A.; Cotton, G. J.; Adeva, A.; Muir, T. W. Chemical ligation of unprotected peptides directly from a solid support. J. Peptide Res. 1998, 51, 303-316; (b) Dawson, P.; Muir, T.; Clark-Lewis, I.; Kent, S. Synthesis of proteins by native chemical ligation. Science 1994, 266, 776-779; (c) Kent, S. B. H. Total chemical synthesis of proteins. Chem. Soc. Rev. 2009, 38, 338-351; (d) Muir, T. W.; Sondhi, D.; Cole, P. A. Expressed protein ligation: A general method for protein engineering. Proc. Natl. Acad. Sci. USA 1998, 95, 6705-6710; (e) Muralidharan, V.; Muir, T. W. Protein ligation: an enabling technology for the biophysical analysis of proteins. Nat. Methods 2006, 3, 429-438; (f) Nilsson, B. L.; Soellner, M. B.; Raines, R. T. Chemical Synthesis of Proteins. Annu. Rev. Biophys. Biomol. Struct. 2005, 34, 91-118.

(4) (a) Fricker, S. P. Cysteine proteases as targets for metal-based drugs. Metallomics 2010, 2 , 366-377; (b) Mandal, S.; Phadtare, S.; Sastry, M. Interfacing biology with nanoparticles. Curr. Appl. Phys. 2005, 5, 118-127; (c) Pace, N. J.; Weerapana, E. Zinc-Binding Cysteines: Diverse Functions and Structural Motifs. Biomolecules 2014, 4, 419-434; (d) Xu, L.; Guo, Y.; Xie, R.; Zhuang, J.; Yang, W.; Li, T. Three-dimensional assembly of Au nanoparticles using dipeptides. Nanotechnology 2002, 13, 725-728; (e) Zhang, J.; Chi, Q.; Nielsen, J. U.; Friis, E. P.; Andersen, 
J. E. T.; Ulstrup, J. Two-Dimensional Cysteine and Cystine Cluster Networks on Au(111) Disclosed by Voltammetry and in Situ Scanning Tunneling Microscopy. Langmuir 2000, 16, $7229-7237$.

(5) (a) Crich, D.; Banerjee, A. Native Chemical Ligation at Phenylalanine. J. Am. Chem. Soc. 2007, 129, 10064-10065; (b) Haase, C.; Rohde, H.; Seitz, O. Native Chemical Ligation at Valine. Angew. Chem. Int. Ed. 2008, 47, 6807-6810; (c) Merkx, R.; de Bruin, G.; Kruithof, A.; van den Bergh, T.; Snip, E.; Lutz, M.; El Oualid, F.; Ovaa, H. Scalable synthesis of $\gamma$-thiolysine starting from lysine and a side by side comparison with $\delta$-thiolysine in non-enzymatic ubiquitination. Chem. Sci. 2013, 4, 4494-4498; (d) Morishita, Y.; Kaino, T.; Okamoto, R.; Izumi, M.; Kajihara, Y. Synthesis of d,1-amino acid derivatives bearing a thiol at the $\beta$-position and their enzymatic optical resolution. Tetrahedron Lett. 2015, 56, 6565-6568; (e) Shang, S.; Tan, Z.; Dong, S.; Danishefsky, S. J. An Advance in Proline Ligation. J. Am. Chem. Soc. 2011, 133, 10784-10786; (f) Wong, C. T. T.; Tung, C. L.; Li, X. Synthetic cysteine surrogates used in native chemical ligation. Mol. BioSyst. 2013, 9, 826-833; (g) Yang, R.; Pasunooti, K. K.; Li, F.; Liu, X.-W.; Liu, C.-F. Dual Native Chemical Ligation at Lysine. J. Am. Chem. Soc. 2009, 131, $13592-13593$.

(6) (a) Chen, S.; Gopalakrishnan, R.; Schaer, T.; Marger, F.; Hovius, R.; Bertrand, D.; Pojer, F.; Heinis, C. Dithiol amino acids can structurally shape and enhance the ligand-binding properties of polypeptides. Nat. Chem. 2014, 6, 1009-1016; (b) Roy, A.; Madden, C.; Ghirlanda, G. Photoinduced hydrogen production in a helical peptide incorporating a $[\mathrm{FeFe}]$ hydrogenase active site mimic. Chem. Commun. 2012, 48, 9816-9818; (c) Sun, Y.; Li, X.-Q.; Meng, Y.-P.; Wang, C. Synthesis of Protected Dithiol Amino Acids for Potential Use in Peptide Chemistry. Synth. Commun. 2008, 38, 3303-3310. 
(7) (a) Goswami, K.; Chakraborty, A.; Sinha, S. Synthesis of Optically Active SeleniumContaining Isotryptophan, Homoiso-tryptophan, and Homotryptophan. Eur. J. Org. Chem. 2013, 3645-3647; (b) Goswami, K.; Paul, S.; Bugde, S. T.; Sinha, S. Synthesis of optically active homotryptophan and its oxygen and sulfur analogues. Tetrahedron 2012, 68, 280-286.

(8) Isidro-Llobet, A.; Álvarez, M.; Albericio, F. Amino Acid-Protecting Groups. Chem. Rev. 2009, 109, 2455-2504.

(9) Spetzler, J. C.; Hoeg-Jensen, T. Tandem ligation at X-Cys and Gly-Gly positions via an orthogonally protected auxiliary group. Bioorg. Med. Chem. 2007, 15, 4700-4704.

(10) Kondasinghe, T. D.; Saraha, H. Y.; Odeesho, S. B.; Stockdill, J. L. Direct palladiummediated on-resin disulfide formation from Allocam protected peptides. Org. Biomol. Chem. 2017, 15, 2914-2918.

(11) Gleiter, R.; Uschmann, J. Electronic structure of heterospirenes. PE spectroscopic investigations. J. Org. Chem. 1986, 51, 370-380.

(12) Firouzabadi, H.; Iranpoor, N.; Hazarkhani, H. Iodine Catalyzes Efficient and Chemoselective Thioacetalization of Carbonyl Functions, Transthioacetalization of O,O- and S,O-Acetals and Acylals. J. Org. Chem. 2001, 66, 7527-7529.

(13) Siciliano, C.; Barattucci, A.; Bonaccorsi, P.; Di Gioia, M. L.; Leggio, A.; Minuti, L.; Romio, E.; Temperini, A. Synthesis of d-erythro-Sphinganine through Serine-Derived $\alpha$-Amino Epoxides. J. Org. Chem. 2014, 79, 5320-5326.

(14) (a) Kwart, H.; Evans, E. R. The Vapor Phase Rearrangement of Thioncarbonates and Thioncarbamates. J. Org. Chem. 1966, 31, 410-413; (b) Lloyd-Jones, G. C.; Moseley, J. D.; Renny, J. S. Mechanism and Application of the Newman-Kwart O $\rightarrow$ S Rearrangement of O-Aryl Thiocarbamates. Synthesis 2008, 661-689; (c) Miyazaki, K. The thermal rearrangement of 
thionocarbamates to thiolcarbamates. Tetrahedron Lett. 1968, 9, 2793-2798; (d) Newman, M. S.; Karnes, H. A. The Conversion of Phenols to Thiophenols via Dialkylthiocarbamates1. J. Org. Chem. 1966, 31, 3980-3984; (e) Zonta, C.; De Lucchi, O.; Volpicelli, R.; Cotarca, L. In SulfurMediated Rearrangements II; Schaumann, E., Ed.; Springer Berlin Heidelberg: Berlin, Heidelberg, 2007; Vol. 275, p 131-161.

(15) (a) Liénard, B. M. R.; Selevsek, N.; Oldham, N. J.; Schofield, C. J. Combined Mass Spectrometry and Dynamic Chemistry Approach to Identify Metalloenzyme Inhibitors. ChemMedChem 2007, 2, 175-179; (b) Mahendran, A.; Vuong, A.; Aebisher, D.; Gong, Y.; Bittman, R.; Arthur, G.; Kawamura, A.; Greer, A. Synthesis, Characterization, Mechanism of Decomposition, and Antiproliferative Activity of a Class of PEGylated Benzopolysulfanes Structurally Similar to the Natural Product Varacin. J. Org. Chem. 2010, 75, 5549-5557; (c) Baco, E.; Hoegy, F.; Schalk, I. J.; Mislin, G. L. A. Diphenyl-benzo[1,3]dioxole-4-carboxylic acid pentafluorophenyl ester: a convenient catechol precursor in the synthesis of siderophore vectors suitable for antibiotic Trojan horse strategies. Org. Biomol. Chem. 2014, 12, 749-757.

(16) (a) Chen, G. H.; Wang, S.; Wu, F. H. A practical synthesis of sarpogrelate hydrochloride and in vitro platelet aggregation inhibitory activities of its analogues. Chin. Chem. Lett. 2010, 21, 287-289; (b) Gurdere, M. B.; Budak, Y.; Gezegen, H.; Ceylan, M. Bromination of 1,4Diphenylbutane-1,4-dione with N-Bromosuccinimide and Bromine in Different Conditions. Asian J. Chem. 2008, 20, 1431-1436.

(17) (a) C. G. Biagini, S.; E. GibsonéThomas, S.; P. Keen, S. Cross-metathesis of unsaturated $\alpha-$ amino acid derivatives. J. Chem. Soc., Perkin Trans. 1 1998, 2485-2500; (b) Frost, J. R.; Jacob, N. T.; Papa, L. J.; Owens, A. E.; Fasan, R. Ribosomal Synthesis of Macrocyclic Peptides in Vitro and in Vivo Mediated by Genetically Encoded Aminothiol Unnatural Amino Acids. ACS Chem. 
Biol. 2015, 10, 1805-1816; (c) Kotha, S.; Singh, K. N-Alkylation of diethyl acetamidomalonate: synthesis of constrained amino acid derivatives by ring-closing metathesis. Tetrahedron Lett. 2004, 45, 9607-9610.

(18) (a) Schneider, H.; Sigmund, G.; Schricker, B.; Thirring, K.; Berner, H. Synthesis of modified partial structures of the bacterial cell wall. 1. Lipopeptides containing nonproteinogenic amino acids. J. Org. Chem. 1993, 58, 683-689; (b) Wu, G.; Kou, B.; Tang, G.; Zhu, W.; Shen, H. C.; Liu, H.; Hu, T. Synthesis of novel and conformationally constrained bridged amino acids as compact modules for drug discovery. Tetrahedron Lett. 2016, 57, 599-602; (c) Young, D. D.; Torres-Kolbus, J.; Deiters, A. Microwave-assisted synthesis of unnatural amino acids. Bioorg. Med. Chem. Lett. 2008, 18, 5478-5480.

(19) (a) Duttagupta, I.; Goswami, K.; Chatla, P.; Sinha, S. Improved Synthesis of Cyclic $\alpha$ Hydrazino Acids of Five- to Nine-Membered Rings and Optical Resolution of 5,6,7-Membered Ring Hydrazino Acids. Synth. Commun. 2014, 44, 2510-2519; (b) Duttagupta, I.; Goswami, K.; Sinha, S. Synthesis of cyclic $\alpha$-hydrazino acids. Tetrahedron 2012, 68, 8347-8357.

(20) (a) Duttagupta, I.; Misra, D.; Bhunya, S.; Paul, A.; Sinha, S. Cis-Trans Conformational Analysis of $\delta$-Azaproline in Peptides. J. Org. Chem. 2015, 80, 10585-10604; (b) Kelleman, A.; Mattern, R.-H.; Pierschbacher, M. D.; Goodman, M. Incorporation of thioether building blocks into an $\alpha v \beta 3$-specific RGD peptide: Synthesis and biological activity. Biopolymers (Peptide Sci.) 2003, 71, 686-695.

(21) GrÖBel, B.-T.; Seebach, D. Umpolung of the Reactivity of Carbonyl Compounds Through Sulfur-Containing Reagents. Synthesis 1977, 357-402.

(22) Burghardt, T. E. Developments in the deprotection of thioacetals. J. Sulfur Chem. 2005, 26, 411-427. 
(23) Behloul, C.; Guijarro, D.; Yus, M. Deallyloxy- and debenzyloxycarbonylation of protected alcohols, amines and thiols via a naphthalene-catalysed lithiation reaction. Tetrahedron 2005, 61, 9319-9324.

(24) Mehta, A.; Jaouhari, R.; Benson, T. J.; Douglas, K. T. Improved efficiency and selectivity in peptide synthesis: Use of triethylsilane as a carbocation scavenger in deprotection of t-butyl esters and t-butoxycarbonyl-protected sites. Tetrahedron Lett. 1992, 33, 5441-5444.

(25) Miles, L. W. C.; Owen, L. N. Dithiols. Part IX. Syntheses with the isopropylidene and benzylidene derivatives of 2 : 3-dimercaptopropanol. J. Chem. Soc. 1950, 2938-2943.

(26) Zhao, X.-Y.; Sun, M.; Wang, J.-X.; Xu, Y.-Z.; Liu, Y.; Zhang, Z.-F.; Lu, L.-Y. Characterization of Tibetan Medicine Zuota by Multiple Techniques. Bioinorg. Chem. Appl. 2013, 198545, 1-11.

(27) Boulard, F.; Baylet, J.; Cardinaud, C. Effect of $\mathrm{Ar}$ and $\mathrm{N}_{2}$ addition on $\mathrm{CH}_{4}-\mathrm{H}_{2}$ based chemistry inductively coupled plasma etching of HgCdTe. J. Vac. Sci. Technol. A 2009, 27, $855-861$.

(28) (a) Cuevasanta, E.; Reyes, A. M.; Zeida, A.; Mastrogiovanni, M.; Armas, M. I. D.; Radi, R.; Alvarez, B. and Trujillo, M. Kinetics of formation and reactivity of the persulfide in the onecysteine peroxiredoxin from Mycobacterium tuberculosis. jbc.org/cgi/doi/10.1074/jbc.RA119.008883; (b) Baez, N. O. D.; Reisz, J. A.; Furdui, C. M. Mass Spectrometry in Studies of Protein Thiol Chemistry and Signaling: Opportunities and Caveats. Free Radic Biol Med. 2015, 80, 191-211.

(29) Muir, B.; Cooper, D. B.; Carrick, W. A.; Timperley, C. M.; Slater, B. J.; Quick, S. Analysis of chemical warfare agents: III. Use of bis-nucleophiles in the trace level determination of phosgene and perfluoroisobutylene. J. Chromatogr. A 2005, 1098, 156-165. 
(30) In HRMS analysis of compound 7a, sometimes diphenylketal deprotected fragments of 7a were found.

(31) AMPAC 10, 1992-2013 Semichem, Inc. 12456 W 62nd Terrace - Suite D, Shawnee, KS 66216.

(32) Gaussian 16 Revision A.03: Frisch, M. J.; Trucks, G. W.; Schlegel, H. B.; Scuseria, G. E.; Robb, M. A.; Cheeseman, J. R.; Scalmani, G.; Barone, V.; Petersson, G. A.; Nakatsuji, H.; Li, X.; Caricato, M.; Marenich, A. V.; Bloino, J.; Janesko, B. G.; Gomperts, R.; Mennucci, B.; Hratchian, H. P.; Ortiz, J. V.; Izmaylov, A. F.; Sonnenberg, J. L.; Williams-Young, D.; Ding, F.; Lipparini, F.; Egidi, F.; Goings, J.; Peng, B.; Petrone, A.; Henderson, T.; Ranasinghe, D.; Zakrzewski, V. G.; Gao, J.; Rega, N.; Zheng, G.; Liang, W.; Hada, M.; Ehara, M.; Toyota, K.; Fukuda, R.; Hasegawa, J.; Ishida, M.; Nakajima, T.; Honda, Y.; Kitao, O.; Nakai, H.; Vreven, T.; Throssell, K.; Montgomery, J. A.; Peralta , J. E. Jr.; Ogliaro „F.; Bearpark, M. J.; Heyd, J. J.; Brothers, E. N.; Kudin, K. N.; Staroverov, V. N.; Keith, T. A.; Kobayashi, R.; Normand, J.; Raghavachari, K.; Rendell, A. P.; Burant, J. C.; Iyengar ,S. S.; Tomasi, J.; Cossi, M.; Millam, J. M.; Klene, M.; Adamo, C.; Cammi, R.; Ochterski, J. W.; Martin, R. L.; Morokuma K.; Farkas, O.; Foresman, J. B.; Fox, D. J.; Gaussian Inc. Wallingford CT 2016. 